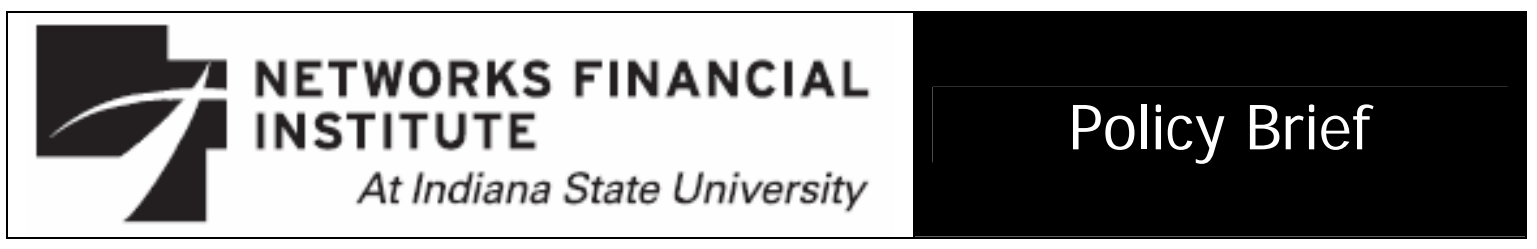

2007-PB-05

March 2007

\title{
China's Changing Financial System: Can It Catch Up With, or Even Drive Growth
}

\author{
James R. Barth and Gerard Caprio, J r.
}

Abstract: Throughout the past three decades of fast growth, China has undergone tremendous structural changes in its economy. There has been significant and continuing industrialization, urbanization and integration into the world economy. The financial system has also undergone major changes, with the People's Bank of China (PBOC) ending its monopoly of the banking sector and being recast as the nation's central bank in the late 1970s and early 1980s. The purpose of this paper is to examine in some detail China's changing financial system so as to assess whether it can catch up with, or even drive economic growth.

About the Authors: James R. Barth is Lowder Eminent Scholar in Finance at Auburn University and Senior Finance Fellow at the Milken Institute, and Gerard Caprio, $\mathrm{J} r$. , is a Professor of Economics and Chair of the Center for Development Economics at Williams College.

Keywords: China, financial regulation, financial system

The views expressed are those of the author and do not necessarily reflect official positions of Networks Financial Institute. Please address questions regarding content to James R. Barth at barthjr@auburn.edu. Any errors or omissions are the responsibility of the author.

NFI working papers and other publications are available on NFI's website

(www.networksfinancialinstitute.org). Click "Research" and then "Publications/Papers." 


\section{China's Changing Financial System: Can It Catch Up With, or Even Drive Growth James R. Barth and Gerard Caprio, J r."}

\section{Introduction}

China has captured the attention of the world with its unprecedented growth for such a big country during the past 28 years. At an average rate of 9.4 percent, China's GDP has grown almost three times the world average. It is now the fourth largest country in the world, behind only the United States, Japan and Germany. ${ }^{1}$ If such rapid growth continues, China's GDP will be larger than that of top three countries in the not too distant future. The pace of economic growth coupled with limits on population growth, moreover, has enabled China to double its GDP per capita three times since 1978. This was the year Vice Premier Deng Xiaoping initiated China's transition from a centrally planned economy to a socialist market economy, two years after the death of Chairman Mao Zedong.

Throughout the past three decades of fast growth, China has undergone tremendous structural changes in its economy. There has been significant and continuing industrialization, urbanization and integration into the world economy. The financial system has also undergone major changes, with the People's Bank of China (PBOC) ending its monopoly of the banking sector and being recast as the nation's central bank in the late 1970s and early 1980s. At the same time four stateowned commercial banks (the so-called "Big Four") were established to take over the role of the PBOC in allocating credit throughout the economy. In the mid-1990s three

\footnotetext{
* The authors are extremely grateful for the excellent assistance provided by Tong Li and Qianfei Wang. ${ }^{1}$ China ranks fourth when GDP is measured on the basis of exchange rates, but second on a purchasingpower basis.
} 
policy development banks were established to relieve the Big Four of the responsibility of making loans to implement the policies of the government, thereby enabling them to operate more fully as true commercial banks.

Beginning in the late 1990s, still further changes in the financial system occurred. The Big Four had accumulated enormous nonperforming loans (NPLs) as a result of their earlier policy-directed lending so the government undertook a series of actions to address this problem. These actions became more urgent when China became a member of the World Trade Organization (WTO) in December 2001 and committed to fully opening up its banking sector to foreign firms by December 2006. The actions taken over several years sufficiently improved the financial condition of three of the Big Four for them to go public in 2005 and 2006, with the last bank doing so being the biggest initial public offering (IPO) in history.

Other changes in the financial system took place as well. In the early 1990s, two stock exchanges were established: one in Shanghai and the other in Shenzhen. Laws were also enacted establishing three new financial regulatory agencies in the 1990s and early 2000s: one each to oversee the banking, securities, and insurance industries. This frees the PBOC of the responsibility to supervise these financial sectors so it can focus on monetary policy. While still more changes will take place, China has already implemented many reforms to improve the functioning of the overall financial system and to promote sustained growth in the economy.

The purpose of this paper is to examine in some detail China's changing financial system so as to assess whether it can catch up with, or even drive economic growth. China has achieved remarkable growth over the past quarter of a century 
despite a relatively inefficient financial system. The allocation of credit was not and is still not based primarily on the basis of risk and return trade-offs despite the shift away from a command and control economy to a more market-oriented economy. The financial system, moreover, is imbalanced in the sense that it is dominated by the banking sector, which to a large degree means the Big Four, with the bond and stock markets still relatively underdeveloped. Firms are therefore mainly dependent on bank loans and retained earnings to finance working capital and investment. At the same time, economic growth is also imbalanced in the sense that it is driven largely by investment and exports, with consumption playing a fairly modest role.

These imbalances in the real and financial sectors are interrelated insofar as the growth in exports has resulted in current account surpluses that have led to substantial foreign currency inflows. This, in turn, has contributed to rapid growth in the money supply and bank credit as the foreign currency is exchanged for domestic currency. This growth has been limited to some extent by sterilization actions in which the PBOC has sold relatively low-yielding bonds of its own to the banks. To lessen the need for those actions China could allow its currency to appreciate far more than it has recently to reduce exports. A side benefit of doing this would be the need to sell fewer bonds to banks which would improve their net interest margins because the interest rate on the POBC bonds is significantly lower than the rate on loans. However, such an appreciation could seriously weaken exporting firms and thereby lead to unemployment and more NPLs for banks that had lent to these firms. A still bigger and related problem is the build-up in investment that is the number one driver in growth. There are already concerns that there is an investment "boom" that may 
soon collapse into a "bust", which if it happens will reduce economic growth and create even more NPLs at banks. All these issues will be explored in this paper.

The plan of the remainder of the paper is as follows. The second section provides a brief overview of China's role in the world economy compared to other select countries. The third section examines the sources of China's economic growth and the unbalanced nature of that growth. The fourth section discusses the opening of China's economy to the world both in terms of the current account and the capital account, including the implications of the recent and substantial cross-border inflow of funds with a relatively pegged exchange rate regime. The fifth section focuses on the financial system, with special emphasis on the banking sector and the potential problems it presents for sustaining China's economic growth. The last section provides a summary and conclusions.

\section{An Overview of China's Economy and Financial System}

All the talk about China being the fastest growing economy today, while certainly true, requires a somewhat broader historical perspective. As Table 1 shows, in 1820 China was not only the biggest country in terms of population but also the biggest in terms of GDP. At that time, India was the second biggest country in terms of both population and GDP. More generally, in the early 1800s there was a positive correlation between the shares of world population and shares of world GDP accounted for by counties. This was mainly due to the agricultural sector being the major contributor to employment and GDP as a result of the still rudimentary state of technological development. The industrial revolution changed things quite 
dramatically for countries around the world. By 2005, India, the largest democracy in the world, was in twelfth place and China, the largest communist country in the world, was in fourth place. The shake-up in rankings reflected the shift to services and manufacturing from agriculture as the major contributors to growth. This was made possible by advances in engineering and production technology and improved human capital that created a change in the composition of GDP for many countries and thereby made population per se less crucial in determining the size of a country's GDP. These developments have enabled countries with relatively small populations to achieve high levels of GDP per capita. Indeed, both China's and India's GDP per capita are far less than the other top ten leading economies listed in Table 1 even though the two Asian Giants account for about 40 percent of the world's population.

Nevertheless, as Chart 1 shows, the recent rapid growth rates in China and India have enabled them to double GDP per capita in fewer years than both the United Kingdom and the United State. ${ }^{2}$ If the rapid growth continues in these countries, their GDPs will exceed today's rich countries in the not too distant future. ${ }^{3}$ A prediction by Goldman Sachs as to exactly when this will happen is provided in Chart 2. ${ }^{4}$ As may be seen, China is expected to pass the United States in 2040 and India to pass Japan in 2030. Furthermore, China ranks second and India ranks tenth among the top ten contributors to world GDP growth from 1995 to 2005 (see Chart 3). Of course, starting from a fairly low level of GDP with underutilized or surplus natural and human resources enables a country to grow much faster than advanced

\footnotetext{
${ }^{2}$ China adopted a one-child policy in 1979, which has contributed to the more than eight-fold increase in GDP per capita in just less than 30 years.

${ }^{3}$ GDP doubles every decade at a growth rate of 7 percent.

${ }^{4}$ Dekle and Vandenbroucke (2006) project GDP growth at about 5.8 percent a year between now and 2040.
} 
countries. This is not to belittle each of these country's recent accomplishments, however, given the lack of similar growth in many other countries with low levels of GDP and less than fully utilized resources.

Table 2 provides a broader perspective of China by comparing it to select countries in terms of shares of world population, GDP, and total financial assets (including bank assets, bonds outstanding and stock market capitalization). It is clear that the world's income and financial assets are not distributed among these countries on the basis of their shares of the world's population. Indeed, China accounts for 20 percent of the world's population but only 5 percent of the world's GDP and 3 percent of the world's financial assets. India is in even a worse comparative position, accounting for 17 percent of the world's population but less than 2 percent of the world's GDP and less than 1 percent of the world's financial assets. In sharp contrast, the United States accounts for less than 5 percent of the world's population but nearly 30 percent of the world's GDP and slightly more than 30 percent of the world's financial assets. It is also clear from the figures that in the case of Japan, the European Union's (EU) 25 member countries ${ }^{5}$ and the United States that each country's share of total financial assets roughly equals its share of world GDP. In the case of China and India, however, their financial asset shares are only two-thirds and one-half of their GDP shares. This reflects the fact that both countries still have relatively underdeveloped financial systems. Furthermore, in China bank assets are twice as large as equities and bonds, whereas in the advanced countries the situation is the reverse. India simply has an underdeveloped banking sector which produces a

\footnotetext{
${ }^{5}$ This excludes Romania and Bulgaria that became member countries in early 2007, which enlarged the EU to 27 members.
} 
financial system composition that more closely approximates that of the advanced countries. The relative size and composition of financial systems is important because the overwhelming evidence to date indicates that more developed and balanced financial systems promote economic growth and development. ${ }^{6}$ Both China and India have ample room to expand the size of their financial systems, including the banking sector and the capital markets, to facilitate continued economic growth and development. ${ }^{7}$ The development of a broader and more diversified financial system, however, should be accompanied by reforms to ensure that savings are allocated to investment projects on the basis of risk and return considerations rather than political connections or cronyism.

\section{Contributors to China's Economic Growth}

China achieved a remarkable growth rate of 9.9 percent in 2005. Table 3 shows the basic contributors to this growth. There are several comments about the information in this table. First, China's growth is imbalanced in the sense that it depends heavily on investment and exports and much less than one might expect on consumption. As may be seen, the situation is nearly reversed in the case of India, with consumption being the major contributor to growth. Corresponding to the low consumption rate is a high saving rate in China. Both households and businesses have high saving rates, at 20 percent and 23 percent, respectively. ${ }^{8}$ This means that China

\footnotetext{
${ }^{6}$ See Levine (1997 and 2005).

${ }^{7}$ See Appendix 1 for a comparison of China and India's financial systems to several other countries.

${ }^{8}$ Many consider the high household saving rate to be due to the lack of adequate health and pension plans. According to China Money (November 7-13, 2005), only 15 percent of the population is covered by the country's pension system. More generally, see Kuijs (2005) for more detailed in formation on investment and saving in China.
} 
is able to finance its investment with internally generated funds, rather than being a net borrower from abroad, which is the more typical case for a developing country. At the same time, as will be discussed more fully below, most household saving flows into the banks, given the underdeveloped capital markets and the relatively strict capital controls that limit the amount of funds that may flow abroad. The savings or retained earnings of firms also tend to stay mainly with the country and to be used to fund further expansion. The saving rate of the state-owned enterprises (SOEs) in particular is quite high because they are not required to pay dividends to their capital owners, namely the government.

Second, investment is clearly the main driver in China's rapid economic growth. It is funded mainly with the retained earnings of firms and loans from banks, with the issuance of stock and bonds playing a relatively minor role, though one that has become more important recently for a growing number of firms. Accounting for a 43 percent share of real GDP in 2004 and still seemingly growing fairly rapidly, there are concerns that investment has led to excess capacity in some sectors of the economy. Indeed, China's Prime Minister Wen recently stated:

"...Beijing is increasingly concerned about the quality of growth. He admitted that it had failed to adequately control investment in fixed assets such as factors and machinery. Overinvestment is among the biggest threats to the economy, as it leads to production gluts and can wipe out corporate profits, causing bankruptcies and a jump in bad loans. 'The problem of excess production is getting worse, corporate profits are down and losses are increasing, causing greater potential financial risks"'(Wall Street Journal, March 6, 2006).

To underscore the concern about overinvestment, Chart 4 shows the relationship between the ratio of investment to GDP and real GDP growth in China over the period 1980 to 2005. As may be seen, whenever the investment-to-GDP ratio reached a peak and then fell, real GDP growth subsequently declined. The chart also shows 
that the ratio is now the highest it has been over the past twenty-five years, which reinforces concerns about an investment boom and then bust, with adverse consequences for economic growth, employment and banks (i.e., NPLs). ${ }^{9}$

Third, the export sector has also been an important contributor to China's growth. Indeed, as Table 3 shows, exports are second only to investment in terms of the contribution made to real GDP growth in 2005. Moreover, exports have exceeded imports every year over the past decade, which only serves to underscore the important role exports have played in China's growth story. Indeed, this fact leads some to refer to China as "Wal-Mart with an army". The contribution of exports to growth and employment has led to tremendous development and urbanization in the eastern coastal areas of China. This situation has created a widening income gap between those working in these areas and those located in the interior. ${ }^{10}$ While the government tries to improve economic conditions in the inland regions of the country, it is also careful to avoid taking any precipitous actions that would adversely affect growth and employment in the export sector, including allowing too much flexibility in its exchange rate too quickly, as will be discussed in the next section.

\section{China's Integration Into the World Economy}

China made a major decision to begin the process of opening its economy to the world in the late 1970s. Chart 5 shows the tremendous strides it has made since

\footnotetext{
${ }^{9}$ Liang (2006, p.22), however, considers investment spending to be overstated and consumption understated. He therefore considers "China's investment cycle [to be]... profitable and sustainable."

${ }^{10}$ The eastern coastal areas account for about two-thirds of GDP and have a GDP per capita that is about twice the national average, according to the China Statistical Yearbook. For more information on these disparities, see Catin, Luo and Van Huffel (2005).
} 
then. Indeed, both China's exports and imports exploded over the past 25 years, increasing nearly 4,000 percent and 3,500 percent, respectively. This is in sharp contrast to the progress that India has made on this score, as the chart shows. The growth, moreover, has far surpassed the growth in world exports/imports over this same period. As a result of this growth, China is now the third largest trading nation in the world when measured by the sum of exports and imports, behind only the Euro area and the United States (see Table 4) ${ }^{11}$ China, moreover, is far more "open" than the United States when openness is measured by the ratio of exports plus imports to GDP. Furthermore, Chart 6 shows there is a fairly close and positive relationship between the growth in China's share of world trade and the growth in its share of world GDP. Once again, in sharp contrast, India's share of world trade has remained relative flat over the past 25 years and so too has its share of world GDP.

At the same time that China has been rapidly integrating into the world economy through trade it has been running a trade surplus for every year since 1990 except for 1993. The surpluses, moreover, have been increasing over time, reaching a record $\$ 177$ billion in 2006. This, of course, means that some other countries have been running trade deficits with China. The country with the biggest trade deficit with China is the United States, which reached a record of $\$ 233$ billion in 2006. ${ }^{12}$ To reduce this deficit, the United States has been pressuring China to allow its currency, the yuan or renminbi (RMB), to fluctuate to a far greater degree than China as so far allowed. ${ }^{13}$ The pressure being applied is based on the reasonable assumption that

\footnotetext{
${ }^{11}$ For purposes of comparison, India ranks 18.

${ }^{12}$ The total trade deficit, however, was $\$ 764$ billion.

${ }^{13}$ In addition, the United States filed a compliant with the WTO in early February 2007 charging China with unfairly subsidizing exports by Chinese companies.
} 
market forces would cause a significant appreciation of the RMB against the U.S. dollar and thereby help reduce the U.S. trade deficit. Chart 7 shows that China had pegged the RMB to the U.S. dollar from 1995 until July 21, 2005, when it revalued its currency against the U.S. dollar by 2.1 percent. (For purposes of comparison, Chart 7 also shows that India has not pegged its currency to the U.S. dollar.) China also put in place a narrow band within which it would allow the RMB to fluctuate on a daily basis with respect to the U.S. dollar, and a slightly wider band within which its currency could fluctuate against a basket of currencies. From July 20, 2005 to February 26, 2006 the RMB has appreciated with respect to the U.S. dollar by about 6.8 percent.

In addition to the current account surpluses, China has been running surpluses on its capital account. As Chart 8 shows, the most important and stable source of private net capital flows to China from 1982 to 2005 has been foreign direct investment (FDI). Its share of world foreign direct investment inflows increased to 8 percent in 2005 from only 0.1 percent in 1980. China is now the largest recipient of this type of investment in the world, which amounted to \$68 billion in 2005 and accumulatively to $\$ 610$ billion at year-end $2005 .^{14}$ In this regard, Whalley and Xin (2006) point out that foreign companies supplying foreign direct investment often form joint ventures with Chinese enterprises supplying land and labor. This is important because they indicate that these Foreign Invested Enterprises (FIEs) account for over 50 percent of exports and 60 percent of imports. Furthermore, Walley and Xin estimate that China's FIEs contributed over 40 percent of China's

\footnotetext{
${ }^{14}$ State Administration of Foreign Exchange (SAFE).
} 
economic growth in 2003 and 2004, and that without this inward FDI, China's overall GDP growth rate would have been 3.4 percentage points lower.

Other types of capital inflows have been more strictly limited and outflows of capital have also been restricted. ${ }^{15}$ China did, however, establish a qualified foreign institutional investor (QFII) program in December 2002 and a qualified domestic institutional investor (QDII) program in April 2006, which set quotas on portfolio inflows and outflows, respectively. At year-end 2006, China had granted QFII quotas of $\$ 9$ billion to more than 40 foreign institutions and \$13 billion in QDII quotas. Also, in April 2006, Chinese firms and residents were allowed to buy more foreign assets. Furthermore, individuals can now convert up to $\$ 20,000$ in RMB to take out of China. ${ }^{16}$ China has chosen to liberalize primarily its capital controls with respect to foreign direct investment inflows, which not only provide funds for investment projects but also much needed technology and managerial skills that can spread to domestic firms throughout the country. ${ }^{17}$

The reason China has retained fairly rigid capital controls with a pegged exchange rate regime is attributed to the events that occurred in East Asia in the summer of 1997. The collapse of the Thai baht in July was followed by a financial crisis in the region. Countries with weak financial systems tried to defend the currency pegs that existed at the time through contractionary measures rather than

\footnotetext{
${ }^{15}$ The QFIIs are allowed to invest in A shares (shares denominated in renminbi). There are also B shares (shares denominated in U.S. or HK dollars) that are available to domestic (since 2002) and foreign (since 1992) investors in China's two stock exchanges. H shares, $N$ shares, and $S$ shares are shares of Chinese companies listed in Hong Kong, New York, or Singapore, respectively. For information on the development of China's stock market, see Wong (2006).

${ }^{16}$ See U.S. Treasury Department (2006).

${ }^{17}$ China is reported to rank 72 out of 132 countries in terms of outward FDI over 2002-2004. See Lane and Schmukler (2006, p.6). This situation may change if China redeploys its huge foreign exchange reserves away from U.S. bond holdings.
} 
abandoning them, even when the pegs became unsustainable and foreign currency reserves were being depleted. As Chart 9 shows, several countries in East Asia suffered severe recessions due to the crisis, but China did not. A difference is that these other countries had not only adopted pegged exchange rate regimes but also had liberalized their capital controls. Although this allowed a surge in capital inflows to finance investment, it made the countries vulnerable to sudden and large financial outflows when investors decided that their financial systems were weak and the currency pegs were not sustainable. In view of what happened, China has proceeded quite cautiously with respect to removing the controls it has placed on the flow of capital funds into and out of the country while it still retains a fairly tightly pegged exchange rate regime.

As result of its exchange rate policy and capital controls, unlike other countries at the same stage of economic development, China has been running surpluses on both its current and capital accounts. ${ }^{18}$ This has enabled China to accumulate an enormous amount of foreign exchange reserves, about $\$ 1.1$ trillion in January 2007, replacing Japan as the world's top holder of such reserves. ${ }^{19}$ Once China allows the RMB to be fully convertible on the capital account, its large reserve holdings can help assure foreign investors that the country can withstand an attack on its currency, thereby preventing what happened in East Asia in 1997-1998. ${ }^{20}$

\footnotetext{
${ }^{18}$ China allowed fully convertibility on the current account in 1996.

${ }^{19}$ This is more than six times the amount in 2000, which was up \$168 billion. Interestingly, Frankel (2006, p. 69), in a comment on a paper by Rooley, Flokerts-Landau, and Garber (2003), points out that in their view: "China is piling up dollars... as part of an export-led development strategy that is rational given China's need to import workable systems of finance and corporate governance."

${ }^{20}$ China's current foreign exchange reserves are 72 percent of its imports in 2006.
} 
China is now the largest exporter of capital in the world, while the United States is the largest importer of capital. ${ }^{21}$ A large portion of China's foreign exchange reserves are invested in U.S. bonds, which has helped keep U.S. interest rates lower than otherwise. To the extent that shifts in the composition of its portfolio away from bonds to equities, and away from U.S. securities to EU securities, prices in world securities markets may undergo significant changes. Indeed, it is reported that the Ministry of Finance has approved the creation of a new institution to manage China's foreign exchange reserves. "The new State Foreign Exchange Investment Corporation will have a very different mandate, including a diversity of assets such as oversees shares, and perhaps even property and direct investments in the West. Reportedly, an initial $\$ 210$ billion in equity investments has already been approved." ${ }^{22}$ At the moment, the securities that China has been accumulating with its growing stock of foreign exchange reserves are assets on the balance sheet of the PBOC. By shifting the composition of the portfolio to higher yielding investments, the PBOC could increase the earnings on its assets. The riskiness of such a newly rebalanced portfolio, however, would also increase. To the extent that a new institution is established to invest a portion of the foreign exchange reserves in higher yielding assets, the risk of sizeable capital losses on the balance sheet of the PBOC is correspondingly reduced.

The build-up in foreign exchange reserves at the PBOC has resulted from sterilization actions taken by the government. To prevent excessive growth in the money supply that would worsen inflation and bank credit that would contribute to overinvestment as foreign currency is exchanged for RMB, the PBOC has been

\footnotetext{
${ }^{21}$ See Dollar and Kraay (2005) for an analysis of this issue with respect to China. Also, see Appendix 2 for a comparison China and India's international investment positions.

${ }^{22}$ Anatole Kaletsky, "Beijing's shift to equities can move markets," The Times, February 12, 2007.
} 
selling bonds paying relatively low interest rates to banks, rates lower than those charged on loans made by banks. This type of operation enables the PBOC to earn profits insofar as the interest earnings on its assets exceeds the interest paid on its liabilities, including the bonds it issues to sterilize foreign currency inflows and the reserves it requires banks to deposit with it. ${ }^{23}$ Indeed, it is reported that the PBOC had gross earnings of $\$ 44$ billion in interest payments in 2006 on its foreign exchange investments, while it had expenses of $\$ 11.5$ billion in interest payments on its debt and on interest for the reserves of commercial banks it holds. ${ }^{24}$

The problem that arises in this situation is that the PBOC is increasing its profits at the expense of the banks; truly commercial banks would not endure this arrangement for long. ${ }^{25}$ The central bank is in essence serving as a financial intermediary insofar as it is channeling a large portion of the savings of the public through the banks into investment, but foreign investment largely not available to the banks or the public due to capital controls. Table 5 provides an example of the effect of this situation by examining the financial statements reported by China Construction Bank as of June 2006. As may be seen, deposits fund 93 percent of total assets and depositors are paid an average rate of 1.49 percent. Yet, loans and advances account for only 55 percent of total assets, while investments in debt securities account for 33 percent, which includes the PBOC securities issued for sterilization purposes. The average yield on loans is 5.34 percent, whereas the

\footnotetext{
${ }^{23}$ The PBOC also increased reserve requirements for banks several times in recent years to help curtail growth in money and credit. Most recently, as of February 25, 2007, banks must keep 10 percent of their deposits with the PBOC (Wall Street Journal, February 20, 2007, p. A10).

${ }^{24}$ Ye Xie, "Chinese central bank seen making a profit," International Herald Tribune, January 7, 2007.

${ }^{25}$ For example, it was the rebellion by Japanese banks against the practice of forcing them to take up government debt with below-market interest rates that helped set off the deregulation of the Japanese banking system in the early 1980s.
} 
average yield on investments is a much lower 2.84 percent. The result is a net interest margin of 2.7 percent. This situation means that Chinese banks are vulnerable to any slowing in loan growth because they derive virtually all of their income from the net interest margin. $^{26}$

The huge amount of foreign exchange reserves that are denominated in U.S. dollars poses a problem for China. Assume for purposes of illustration that 70 percent of the $\$ 1$ trillion in reserves are denominated in U.S. dollars. This means that a 6.5 percent appreciation of the RMB against the U.S. dollar results in a capital loss of $\$ 45.5$ billion. Of course, total reserves were not this high since China allowed its currency to appreciate against the U.S. dollar in July 2005. Also, the remaining 30 percent of the reserves are denominated in other foreign currencies against which the RMB may have depreciated. Nevertheless, depending on the degree to which the reserves are hedged, the fact that the RMB is most tightly pegged to the U.S. dollar means that any appreciation creates capital losses for the PBOC. It also creates potential problems for exporting firms that receive revenue in U.S. dollars and that have outstanding bank loans in RMB, unless such exchange rate risk has been properly hedged. The banking sector, however, is less exposed to this exchange rate risk because it has less than 5 percent of its assets, and about the same percentage of its liabilities, denominated in foreign currencies. Furthermore, the expectation of further appreciation has contributed to "hot money" flows into China, particularly into the real estate sector with a view towards selling the real estate and reaping both capital gains and exchange rate gains after a significant degree of appreciation occurs.

\footnotetext{
${ }^{26}$ Unlike banks in the United States, Chinese banks earn relatively little of their total income from noninterest revenue-only 6.7 percent in the case of China Construction Bank.
} 
Chinese officials are well aware of the problems resulting from current and capital account surpluses with its currency pegged within a fairly narrow trading range. But they are also acutely aware of the risk of any major changes in relaxing capital controls and widening the trading band for the RMB, and are attempting the difficult task of pursuing sustainable economic growth without the ability to use macro-monetary tools to prevent excessive growth in both money and credit. Instead, China is relying on various micro-monetary tools to prevent serious disruptions to investment and export growth that would worsen unemployment until more balanced growth can occur. Given the crucial role that banks play in this "balancing act," the next section examines in greater detail their position in the overall financial system and their recent condition and current prospects as drivers of growth.

V. The Structure, Performance, and Risks of China's Financial System ${ }^{27}$

China has a bank-centered financial system, much more so than either India or the United States, as Chart 10 shows. Indeed, operating in a capital markets-oriented financial system, firms in the United States have a greater opportunity to access external funds by selling stocks and bonds, thereby significantly lessening the need to rely on credit from banks. ${ }^{28}$ This difference in financial system development is not surprising: arms-length finance, such as corporate debt and equity, requires a much more sophisticated, timely, and reliable information network, compared with bank finance. As a result, these parts of the financial system usually develop later, leaving most developing

\footnotetext{
${ }^{27}$ For current and detailed information on the laws and regulations pertaining to the financial restructuring and reform that has taken place in China, see Barth, et. al. (2007).

${ }^{28}$ Of course, in the most countries, including the United States, small and medium size enterprises (SMEs) typically encounter problems when trying to obtain external funding. Venture capital funds can provide same, albeit limited, assistance in this regard.
} 
economies with a heavily bank-based system. Yet a balanced financial system is desirable. Most importantly, when the financial condition of banks deteriorates and loan growth is curtailed, firms are more easily able to obtain alternative funding in a more balanced financial system than the one that currently exists in China.

The Chinese government recognizes this situation and has taken actions to facilitate further development of its capital markets. For example, revisions were made to the Company Law and Securities Law, which became effective January 1, 2006, that strengthen minority shareholder rights, and beginning on April 2005 all non-tradable shares in SOEs listed on China's two stock exchanges were required to be converted into tradable shares, which will eliminate the problem of the overhang of state-owned shares. The SOEs constitute about 70 percent of the 1,400 listed companies in China. As of January 2006, the share conversion process had been completed in companies that account for about 50 percent of the total market capitalization of the domestic stock exchanges. Also, on February 15, 2006, the Ministry of Finance issued new accounting practices that will bring Chinese accounting practices largely in line with International Financial Reporting Standards (IFRS) ${ }^{29}$ Furthermore, the development of the corporate bond market, as well as banks, will benefit by better protecting the rights of creditors. Specifically, a new Enterprise Bankruptcy Law was approved by the National People's Congress. The importance of the law is as follows:

"The law, to take effect June 1, 2006, will replace rules issued in 1986 that applied only to state-owned enterprises. China's bankruptcy rules require insolvent companies to pay off obligations to employees before they address creditors' claims. The new law, which governs state-owned and privately owned companies, requires companies that go bankrupt to pay guarantees to creditors first, with employee salaries and other obligations paid out of what remains, the official Xinhua news agency said. Experts have long complained that China's rules offered scant protection for creditors and give little

\footnotetext{
${ }^{29}$ See Institute of International Finance (2006).
} 
guidance for dealing with insolvent companies in an increasingly market-driven economy" (Wall Street Journal, August 28, 2006-A4).

Although banks account for 73 percent of the total financial assets in China (see Chart 10), the Big Four account for roughly 60 percent of total bank assets, or just under half of all financial assets. Chart 11 shows the different shares of total assets of all financial institutions in China by type of institution. ${ }^{30}$ The Big Four clearly dominate in terms of total assets, total loans, and total deposits, at shares of 60, 60 and 65 percent, respectively. The concentration of financial assets in just four institutions underscores all the attention they receive because in a way they provide a major indicator of the health of the entire financial system and, more broadly, the economy.

Between the formation of the People's Republic of China in 1949 and late 1970, the PBOC functioned as both a central bank and as the primary commercial bank. It engaged in deposit-taking and lending activities in accordance with the central plan of the government. This "monopoly" of the banking sector ended in 1979 when the PBOC gave up part of its commercial operations with the formation of the Agricultural Bank of China $(\mathrm{ABC})$ and the Bank of China (BOC). This was followed by giving up the remainder of its commercial banking operations with the formation of China Construction Bank (CBC) and the Industrial and Commercial Bank of China (ICBC) in 1983. These four institutions, the Big Four, simply continued providing the commercial banking functions previously provided by the PBOC, with ABC specializing in agricultural financing, BOC specializing in foreign exchange and trade financing, CBC specializing in construction and infrastructure financing, and ICBC specializing in urban commercial financing. The

\footnotetext{
${ }^{30}$ In 2005, there were roughly 35,000 financial institutions in China, with about 33,000 being rural credit cooperatives. There were 4 state-owned commercial banks (Big Four), 3 policy development banks, 13 joint-stock commercial banks, 112 city commercial banks, and 681 city credit cooperatives, among other financial institutions.
} 
PBOC was designated by the State Council as the nation's central bank and the regulator and supervisor of the banking system.

To improve the commercialization of the banking industry in the 1980s, the Big Four were allowed to expand into new commercial banking businesses beyond those in which they had specialized. New commercial banks and other nonbank financial institutions were established beginning in the late 1980s to develop a more modern financial system. This included joint-stock commercial banks with nationwide banking licenses and urban commercial banks with licenses to engage in commercial banking activities within their designated geographic areas. ${ }^{31}$ Then, in 1994, three policy development banks, the China Development Bank, the Export-Import Bank of China, and the Agricultural Development Bank of China, were established to take over the policy lending functions of the Big Four. ${ }^{32}$ In 1995, the National People's Congress passed the Commercial Banking Law, which enabled the Big Four to operate more like genuine commercial banks and segregated the business operations of banks, securities firms and insurance companies. This separation subsequently led to the establishment of three separate regulatory agencies to oversee each industry. The China Securities Regulatory Commission (CSRS) was established in 1992 to initially to oversee the two stock exchanges but also given supervisory responsibility of the securities market in 1998. The China Insurance Regulatory Commission (CIRC) was established in 1998 to oversee the

\footnotetext{
${ }^{31}$ Prior to China becoming a member of the WTO, foreign banks were allowed to set up representative offices in China since 1979 and foreign banks were approved to establish branches in 1981. In December 1996 and August 1998, qualified branches of foreign banks were allowed to offer RMB products. Zhu Xinqing, "Development of China Banking Industry and Restructuring Practices of BOC," PowerPoint presentation, Chicago, IL November 4-5, 2004.

32 Also, beginning in 1994, the government was precluded from borrowing from the PBOC to finance any budget deficits. This helped stimulate the growth in the bond market. It is reported, moreover, that China Development Bank is being considered by the government for conversion into a commercial bank. (XFN News, January 8, 2007)
} 
insurance industry. Lastly, the China Banking Regulatory Commission (CBRC) was established in 2003 to oversee the banking industry. These three agencies assumed the majority of the regulatory and supervisory functions of the PBOC over financial institutions. ${ }^{33}$ Figure 1 shows the regulatory structure of China's financial sector.

If the transition from a centrally planned economy to a socialist market economy was to be successful, the banking sector had to be relived of the burden of holding large amounts of NPLs that had accumulated over the years. The Big Four in particular had historically been collecting deposits and then using them to fund projects as directed by the government. Credit was not allocated on the basis of risk and return considerations, which are crucial in a market-oriented economy to ensure the efficient allocation of credit. To put the Big Four in a position to pay greater attention to risk and return tradeoffs required that their balance sheets be strengthened by removing NPLs that represented a legacy of past practices and simultaneously by increasing their capital. Strengthening the financial condition of the Big Four became especially important once China became a member of the World Trade Organization (WTO) on December 11, 2001 and committed to open up its banking sector in phases over a five-year period that ended on December 11, 2006 (see Table 6). ${ }^{34}$ By removing bad loans and increasing capital, the goal of the government has been to enable the Big Four to become internationally competitive banks.

To assist in addressing the loan problems of the Big Four, four asset management companies (AMCs), Cinda, Oriental, Great Wall and Huarong, were established in 1999,

\footnotetext{
${ }^{33}$ For detailed information on China's laws and regulations pertaining to the financial sector, see Barth, et. al. (2007).

${ }^{34}$ In November 2006, China said it would fulfill its WTO commitment of giving foreign banks full access to its banking market if they incorporate their China operations locally (Wall Street Journal, February 8, 2007, p.C4). This requirement is related to the plan by the Chinese government to introduce a system of deposit insurance insofar as deposits in branches outside a bank's home country can be uninsured, which is the case for branches of a U.S. bank located outside the country.
} 
one initially designated for each of the four state-owned banks. At that time $\$ 169$ billion of NPLs were transferred from the Big Four to the AMCs in exchange for ten-year bonds with an annual interest rate of 2.25 percent. ${ }^{35}$ Overall, $\$ 200$ billion in NPLs was transferred to the AMCs or sold to other entities from 1999 to 2006. In addition, $\$ 80$ billion in capital was injected into the Big Four from 1998 to 2006, with $\$ 45$ billion to BOC and CCB in 2005 and $\$ 15$ billion to ICBC in $2005 .{ }^{36}$ As a result of these efforts the NPL ratios (i.e., nonperforming loans to total loans) of each of the Big Four have declined sharply from 2001 to 2005, as may be seen in Table $7 .{ }^{37}$ However, it is obvious that while three of the banks have seen their ratios fall below 5 percent, the fourth, $\mathrm{ABC}$, still has an enormously high ratio of 26 percent.

Table 8 shows the NPLs transferred to the AMCs as well as how much has been disposed of and what value has been received in exchange. As of December 2005, the AMCs had resolved \$104 billion of \$156 billion of NPLs acquired, generating \$22 billion in cash proceeds. To the extent that the AMCs are unable to make good on the bonds they have given the Big Four in exchange for the NPLs, the government will have to assume this obligation to prevent the banks from absorbing any losses. Still, there is the significant risk that even banks whose balance sheets have been cleaned of substantial

\footnotetext{
${ }^{35}$ The AMCs had a mandate when established to clean up all the NPLs they acquired within 10 years (i.e., 2008). The NPLs transferred in 1999 were made prior to 1996, and classified under the four-tier category system as being overdue for more than one year.

${ }^{36}$ Foreign firms have also injected capital into Chinese banks through the acquisition of ownership shares, although the total foreign ownership in a bank is limited to less than 20 percent for a single investor and to less than 25 percent for all foreign investors.

${ }^{37}$ In January 2002, a new five-category loan classification system was introduced. Under this system, commercial banks are required to classify their loans into the following 5 categories: "pass", "special mentioned", "sub-standard", 'doubtful" and "loss". A loan is classified as "non-performing loan" if it is classified as "sub-standard", "doubtful" or "loss". Also, a new provisioning system was introduced, requiring general provisions of 1 percent of total loans classified as pass to cover potential losses, and specific provisions of 2, 25, 50 and 100 percent of the amount of loans classified as special mentioned, substandard, doubtful and loss, respectively. CBRC required that the Big Four and the joint stock commercial banks adopt this classification system from 2004 and for all banks by the end of 2005. The provisioning requirements will need to be implemented by the end of 2008.
} 
amounts of NPLs will continue to get into difficulty. More generally, the NPL situation, at least in publicly available figures, for the entire banking sector in China for year-end 2005 is shown in Table 9. While the Big Four account for 82 percent of all the NLPs in the banking sector, the other domestic banks clearly have had their own loan problems.

To put the NPL situation in somewhat broader perspective, Table 10 shows the equity-to-asset ratios for each of the Big Four. Comparing these ratios to the corresponding NPL ratios in Table 7 one sees the fairly precarious condition of all four institutions, especially ABC, which for all practical purposes is insolvent based upon its real net equity position. ${ }^{38}$ To put the condition of the Big Four in better perspective, various performance measures of each of the Big Four are compared to the foreign commercial banks (FCB) operating in China and Citibank. ${ }^{39}$ As Table 11 shows, each of the Big Four has substantial room for improvement based upon these measures before being in as good an overall financial condition as Citibank. The Chinese bank in the best overall condition is $\mathrm{CCB}$, while $\mathrm{ABC}$ is in the worst condition. What is particularly noticeable is that each of the Big Four has loan loss reserves that are less than 100 percent of its NPLs, whereas in the case of Citibank the percentage is nearly 160 percent. By not provisioning more for NPLs, net income for each the Big Four is higher than otherwise. Despite this situation, however, BOC, CCB, and ICBC were able to raise substantial amounts of new capital with initial public offerings (IPOs). Specifically, CCB went public in October 2005 and raised \$8 billion, BOC went public in May 2006 and

\footnotetext{
${ }^{38}$ The Chinese government is well aware of this situation and has recently reported that ABC will be recapitalized.

${ }^{39}$ As of June 2006, 71 foreign-funded banks have opened 214 operational institutions in China; in particular, 25 cities have been opened for corporate RMB business; 26 foreign financial institutions have made equity investment in 18 domestic banks totaling US\$17.9 billion; 23 joint-venture fund management companies and 8 joint-stock securities companies have been established; 42 foreign entities have become QFIIs (Governor Zhou Xiaochuan, PBOC, Sept. 21, 2006).
} 
raised \$11 billion, and ICBC went to public in October 2006 and raised \$22 billion, the latter being the biggest IPO in history at the time. ${ }^{40}$

The biggest concern at the moment for China's banking sector is the rapid growth in bank credit that is being used to finance various investment and real estate projects, as noted earlier. Loan growth was 21.4 percent in 2003, 16.3 percent in 2004, and 15.2 percent in 2005, far faster growth than growth in nominal GDP. Chart 12 shows the improvement in the aggregate NPL ratio for the Big Four as already discussed. It is clear that there has been a dramatic reduction in that ratio to less than 10 percent from nearly 30 percent. The chart also shows, however, that at the same time the total loans of the Big Four have almost doubled in amount. The amount of NPLs has declined but not in proportion to the increase in total loans. It is therefore no surprise that the NPL ratio has declined quite sharply over the past several years. The issue now is what portion of all the new loans that have been made in recent years will become nonperforming loans as they age. If enough of them are contributing to the "excess production" noted by Prime Minister Wen then China's banks may need help in disposing of NPLs once again. It is worth noting that if this happens it would not be unique to China. Many transitional country governments have tried to "commercialize" state-owned banks, and discovered that it is difficult to produce a lasting change in incentives within these institutions without a change in ownership. Thus, for example, Hungarian authorities recapitalized their state banks annually from 1991 to 1994, before finally selling those banks to foreign investors. The banks continued making losses for a few more years (before becoming profitable), but it was foreign shareholders who suffered. And Polish authorities,

\footnotetext{
${ }^{40}$ In 2005, the total assets of CCB are 5,166,242; ICBC are 6,454,106; BOC are 4,742,806 and ABC are 4,771,020, all in RMB million.
} 
recognizing the problems with reforming state banks and yet not willing to sell them all immediately, chose to use stock options, which could only be exercised after privatization, to align managerial incentives with the goal of true commercialization.

The bottom line, as suggested earlier and also as seen in other transition countries, is that banks cannot be reformed in isolation. To the extent that state enterprises still are making losses, they will require financing, and China's banks may be pressed to comply. After all, the banking sector can perform no better than the enterprise sector and the financial sector infrastructure permit.

Apart from this potential problem, China's banking sector has another issue that merits constant attention in the transition from a centrally planned economy to a socialist market economy. This issue involves the development of a "credit culture" in which risk and return considerations are the primary determinants in the allocation of credit. This requires well-trained accountants, lawyers and risk analysts who are capable of implementing a policy in which banks price loans on the basis of risk and credit be made available to firms of all sizes and ownership structures on equal terms. China currently has a shortage of such skilled individuals. Furthermore, as regards pricing, Chart 13 shows that before 2004 the rates charged on loans and paid on deposits at banks were tightly regulated by the government so as to lock in a predetermined net interest margin. This was done by setting benchmark rates based upon which bank rates were allowed to vary only within specified limits. ${ }^{41}$ Available information indicates that lending and deposit rates at banks are fairly well clustered even after 2004, however, which limits competition among banks for deposits and suggests loans are not being priced fully on

\footnotetext{
${ }^{41}$ See Ong (2004).
} 
the basis of risk. ${ }^{42}$ Again, this pattern was seen in other transition countries, with loan pricing being driven more by the needs and condition of the enterprise sector than the requirements of commercial banks. Podpiera (2006) finds that lending rates do not differentiate among different credit risks, and that banks seem to lend without regard to enterprise profitability. This behavior is consistent with that in other transitional economies in which the state enterprise sector had yet to downsize as much as needed, and were still absorbing a large share of bank credit.

As regards the allocation of credit, Chart 14 shows that private and foreign enterprises contribute slightly more than half of GDP, but receive only about one-fourth of total corporate loans from banks. Conversely, state-owned enterprises and collective enterprises contribute only about one-forth percent of GDP but receive nearly half of corporate loans from banks. This suggests that credit is being allocated inefficiently, perhaps due still to excessive local, if not central, government influence in bank lending decisions, and is consistent with the lack of differentiation according to credit risk, just noted above. ${ }^{43}$ Chart 15 reinforces this view, by showing that small and medium size enterprises (SMEs) contribute a disproportionate amount to GDP but receive a small proportion of bank loans. Liang (2006, p.22) points out that "[i]n the least developed provinces, overall $60 \%$ of financing for the small-and-medium-sized enterprises (SME) comes from informal sources (sometimes over $70 \%$ ), while the corresponding share is $30 \%$ in coastal areas." Furthermore, Liang indicates that "[t]he interest rates charged by informal financial institutions are significantly above the lending rates charged by the state-owned banks."

\footnotetext{
${ }^{42}$ See Dobson and Kashyap (2006).

${ }^{43}$ Du and Girma (2007, p.37) report that "[u]ntil 1998, the four state-owned commercial banks...were instructed not to lend to private enterprises."
} 
More generally, President $\mathrm{Hu}$ Jintao's signature slogan is the drive for a "harmonious society"-one that would bridge the widening income gaps and ease the strains that are causing social unrest. (Wall Street Journal, November 22, 2006, p. A4). As applied to financial development, Mr. Xiang Junbo, Deputy Governor of PBOC, stated on September 1, 2006, that:

"Financial industry is the core of modern economy. More efforts should be made to build a harmonious financial system compatible with the comprehensive, balanced and sustainable economic development. To be explicit, we will make efforts in the following aspects. First, harmonize the relationship between economic and financial development. Second, foster a harmonious system for financial institutions. Third, build a harmonious financial market. Fourth, promote the development of regional financial industry in a harmonious way. Fifth, blueprint the harmonious reform, development and opening-up of financial industry."

These are certainly commendable goals and hopefully ones that will be achieved through the recent and ongoing reforms in China's financial system.

\section{Summary and Conclusions}

China is undoubtedly unique, and abounds both with substantial opportunities and with significant challenges. Its rapid rate of GDP growth and the boom in exports and international reserves are without precedent. The latter phenomenon of course is a joint product: not only is it unprecedented for an emerging market to be such a large creditor, but it is equally unique for a reserve currency country to be such a large debtor. Still, the reserve buildup is at least in part a testimony to China's competitiveness and of course to its massive savings rate. Moreover, by joining the WTO and welcoming capital inflows, it is signaling a desire to open its economy to international influences and, in turn, to influence international developments. 
The government likewise is to be commended for taking on the challenge of reforming an immense financial system. This sector is a challenge because it is necessarily the mirror image of the real economy, and accordingly cannot be reformed in isolation. To the extent that there are "zombie enterprises", that is, firms that are dead in the sense of not being able to be managed without sustaining losses and yet still alive and utilizing resources, then the financial sector, and usually the banks, will be called on to provide funding. Since the state enterprise sector is still large, the government faces the daunting task of transforming the zombie enterprises into viable enterprises. The balancing act being undertaken by authorities is to keep managing the economy so that the rapid growth from the non-state sector will be able to cover the losses of the statesector.

Chinese officials are aware of this challenge. Unfortunately, the problems do not end there. The further difficulty is that just as the public sector around the world has not proved to be an efficient manager of enterprises, it also has not been an efficient manager of banks. ${ }^{44} \mathrm{~A}$ solution that would seem to work in theory would be to grow the private sector's role in the banking system, using banks that operate on market principles as a way to continually starve inefficient enterprises of credit, while supplying credit to the productive enterprises. Finding a way to make this work in practice will require both finesse and good fortune on a scale commensurate with China's growing importance in the world economy.

\footnotetext{
${ }^{44}$ The French banking system used to be cited as an exception to this statement, until the massive failure of Credit Lyonnais. And the German banking system, the other exception, has been beset by inefficiency and losses in their state banks.
} 


\section{References}

Allen, Franklin, Jun Qian and Meijun Qian. 2005. “China’s Financial System: Past, Present, and Future.” Wharton Center for Financial Institutions Working Paper No. 0517.

Asian Development Bank. 2004. "People's Republic of China.” in Asian Development Outlook 2004. New York, USA: Oxford University Press, pp. 65-75.

Bank for International Settlements. 1999. "Strengthening the Banking System in China: Issues and Experiences.” Bank for International Settlements Policy Papers No. 7.

Barth, James R., Douglas Arner, Berry Hsu, Wei Wang and Zhou Zhongfei, editors. 2007. Financial Restructuring and Reform in Post-WTO China, Kluwer Law International.

Barth, James, Gerard Caprio, Jr., and Ross Levine. 2006. Rethinking Bank Regulation: Till Angels Govern. New York, USA: Cambridge University Press.

Boyreau-Debray, Genevieve and Shang-Jin Wei. 2005. "Pitfalls of a State-Dominated Financial System: The Case of China.” NBER Working Paper No. 11214.

Brandt, Loren and Xiaodong Zhu. 2002. "What Ails China? A Long-Run Perspective on Growth and Inflation (or Deflation) in China." East Asia in Transition: Economic and Security Challenges, edited by A.E. Safarian ad Wendy Dobson, University of Toronto Press.

Catin, Maurice, Xubei Luo and Christophe Van. Huffel. 2005. "Openness, industrialization and geographic concentration of activities in China." World Bank Policy Research Working Paper 3706.

Chen, Jianguo, Ben Marshall, Jenny Zhang, and Siva Ganesh. "Financial Distress Prediction in China.” Review of Pacific Basin Financial Markets and Policies, Forthcoming.

Chen, Xiaogang, Michael Skully, and Kim Brown. 2005. "Banking Efficiency in China: Application of DEA to Pre- and Post-Deregulation Eras: 1993-2000.” China Economic Review, 16:3, pp. 229-45.

Chen, Zhian, Donghui Li, and Fariborz Moshirian. 2005. “China's Financial Services Industry: The Intra-industry Effects of Privatization on the Bank of China Hong Kong." Journal of Banking and Finance, 29, pp. 2291-324.

China Banking Regulatory Commission, 2007. http://www.cbrc.gov.cn

China Insurance Regulatory Commission, 2007. http://www.circ.gov.cn 
China Quarterly Update. August 2006.

China Securities Regulatory Commission, 2007. http://www.csrc.gov.cn

Claessens, Stijn, Asli Demirguc-Kunt, and Harry Huizinga. 1998. "How Does Foreign Entry Affect the Domestic Banking Market.” World Bank Policy Research Working Paper No. 1918.

Clarke, George, Robert Cull, and Mary Shirley. 2005. "Bank Privatization in Developing Countries: A Summary of Lessons and Findings.” Journal of Banking and Finance, 29, pp. 1905-30.

Crystal, Jennifer, Gerard Dages, and Linda Goldberg. 2002. "Has Foreign Bank Entry Led to Sounder Banks.” Current Issues in Economics and Finance, 8:1, pp. 1-6.

Das, Udaibir, Marc Quintyn, and Kina Chenard. 2004. "Does Regulatory Governance Matter for Financial System Stability? An Empirical Analysis.” International Monetary Fund Working Paper 04/89.

Dekle, Robert and Guillaume Vandenbroucke. 2006. "Whither Chinese Growth? A Sectoral Growth Accounting Approach." mimeo.

Demirguc-Kunt, Asli and Enrica Detragiache. 1997. "The Determinants of Banking Crises: Evidence from Industrial and Developing Countries.” World Bank Policy Research Working Paper No. 1828.

Demirguc-Kunt, Asli and Enrica Detragiache. 1999. "Financial Liberalization and Financial Fragility.” World Bank Policy Research Working Paper No. 1917.

Demirguc-Kunt, Asli and Enrica Detragiache. 2005. "Cross-Country Empirical Studies of Systemic Bank Distress : A Survey.” World Bank Policy Research Working Paper No. 3719.

Dobson, Wendy and Anil K. Kashyap. 2006. "The Contradiction in China's Gradualist Banking Reforms." Brookings Papers on Economic Activity, 2.

Dollar, David and Aart Kraay. 2005. "Neither a Borrower Nor a Lender: Does China's Zero Net Foreign Asset Position Make Economic Sense?" World Bank Policy Research Working Paper 3801.

Domac, Ilker and Maria Soledad Martinez-Peria. 2000. "Banking Crises and Exchange Rate Regimes: Is There a Link?” World Bank Policy Research Working Paper No. 2489.

Eichengreen, Barry and Andrew K. Rose. 1998. "Staying Afloat When the Wind Shifts: External Factors and Emerging-Market Banking Crises.” NBER Working Paper No. 6370. 
Eichengreen, Barry and Carlos Arteta. 2000. "Banking Crises in Emerging Markets: Presumptions and Evidence.” Center for International and Development Economics Research (CIDER) Working Papers C00-115.

Eichengreen, Barry. 2006. "China's Exchange Rate Regime: The Long and Short of It." Columbia University's Conference on Chinese Money and Finance.

Fan, He. 2002. “How Far is China Away from a Financial Crisis.” Thailand Development Research Institute.

Fang, Xinghai. 2005. "Reconstructing the Micro-Foundation of China’s Financial Sector.” in Financial Sector Reform in China. Yasheng Huang, Tony Saich and Edward Steinfeld eds. Cambridge, Massachusetts: Harvard University Asia Center 2005, pp. 1928.

Garcia-Herrero, Alicia, Sergio Gavila and Daniel Santabarbara. 2006. "China's Banking Reform: An Assessment of Its Evolution and Possible Impact." CESifo Economic Studies, Vol. 52, 2. 304-363.

Goldstein, Morris and Nicholas Lardy. 2004. "What Kind of Landing for the Chinese Economy.” Institute for International Economics Policy Briefs in International Economics No. PB04-7.

Goldstein, Morris and Nicholas Lardy. 2005. "China's Role in the Revived Bretton Woods System: A Case of Mistaken Identity.” Institute for International Economics Working Paper No. 05-2.

Goldstein, Morris. 2004. “Adjusting China's Exchange Rate Policies.” Institute for International Economics Working Paper No. 04-1.

Goldstein, Morris. 2005. “Renminbi Controversies.” Prepared for the Conference on Monetary Institutions and Economic Development, Cato Institute.

Hu, Fred. 2001. "China's WTO Accession as a Catalyst for Capital Account Liberalization.” Cato Journal, 21:1, pp. 101-11.

Institute of International Finance, Inc. 2006. "Corporate Governance in China: An Investor Perspective." Task Force Report.

International Monetary Fund. 2005. “People’s Republic of China: 2005 Article IV consultation-Staff Report; Staff Supplement; and Public Information Notice on the Executive Board Decisions.” IMF Country Report NO. 05/411.

Kaminsky, Graciela and Carmen Reinhart. 1999. "The Twin Crises: The Causes of Banking and Balance-of-Payment Problems.” The American Economic Review, 89:3, pp. 473-500. 
Klingebiel, Daniela. 2000. “The Use of Asset Management Companies in the Resolution of Banking Crises: Cross-Country Experiences.” World Bank Policy Research Working Paper No. 2284.

Kuijs, Louis. 2005. “Investment and Saving in China.” World Bank Policy Research Working Paper No. 3633.

Lane, Philip R. and Sergio Schmukler L. 2006. "The International Financial Integration of China and India." IMF-World Bank Annual Meetings in Singapore.

Levine, Ross. 1997. "Financial Development and Economic Growth: Views and Agenda." Journal of Economic Literature.

Levine, Ross. 2005. "Finance and Growth: Theory and Evidence.” in Philippe Aghion and Steven Durlauf, eds. Handbook of Economic Growth. The Netherlands: Elsevier Science.

Liang, Hong. 2006. "China's Investment Strength is Sustainable." Goldman Sachs Global Economics Paper No: 146.

Lin, Changyuan. 2003. "Financial Conglomerates in China.” Chinese Academy of Social Sciences, Center for International Law Studies Working Paper No. 2003020011.

Ma, Guonan. 2006. "Sharing China's Bank Restructuring Bill." China \& World Economy, Vol. 14, 19-37.

Makin, John. 2004. “China: The Unplannable, Planned Economy.” American Enterprise Institute for Public Policy Research Economic Outlook.

Mao, Yiwen. 2002. "Establishing China's Financial Vulnerability Indicator System after WTO Accession.” Economic Science, 5, pp. 11-18. 毛一文

“进入WTO后中国金融鵤弱生监测指标体系之设计”《经剂科学》2002年第期

McKinnon, Ronald and Gunther Schnabl. 2003. "China: A Stabilizing or Deflationary Influence in East Asia? The Problem of Conflicted Virture.” Mimeo, Department of Economics, Stanford University.

McKinnon, Ronald. 2005a. “China’s New Exchange Rate Policy: Will China Follow Japan into a Liquidity Trap?” Mimeo, Department of Economics, Stanford University.

McKinnon, Ronald. 2005b. "Exchange Rate or Wage Changes in International Adjustment? Japan and China versus the United States.” Center for European Economic Research Discussion Paper No. 05-64.

Ministry of Finance, People's Republic of China. 2006. http://www.mof.gov.cn

Moreno, Ramon. 2002. "Reforming China's Banking System.” Federal Reserve Bank of San Francisco Economic Letter No. 2002. 
National Bureau of Statistics, 2007. http://www.stats.gov.cn

OECD. 2005. Economic Surveys: China. Paris: OECD Publishing.

Ong, Lynette. 2004. "Flexible rates boost bank reform in China." Asia Times Online, January 8.

Park, Albert, and Sehrt, Kaja. 2001. “Tests of Financial Intermediation and Banking Reform in China.” Journal of Comparative Economics, 29:4, pp. 608-44.

Pei, Guifen and Sayuri Shirai. 2004. "China's Financial Industry and Asset Management Companies: Problems and Challenges." The $21^{\text {st }}$ Century Center of Excellence ProgramPolicy Innovation Initiative: Human Security Research in Japan and Asia.

People's Bank of China. 2005. “2005 China’s Financial Stability Report.” People's Bank of China. Translated by the Milken Institute staff.

People's Bank of China. 2007. http://www.pbc.gov.cn/english/

Podpiera, Richard, 2006"Progress in China's Banking Sector Reform: Has Bank Behavior Changed?" IMF Working Paper WP/06/71.

Prasad, Eswar, Thomas Rumbraugh, and Qing Wang. 2005. "Putting the Cart Before the Horse? Capital Account Liberalization and Exchange Rate Flexibility in China." China \& World Economy, 13:4, pp. 3-20.

Sachs, Jeffery D. and Wing Thye Woo. 2003. "China's Growth after WTO Membership.” Journal of Chinese Economics and Business Studies, 1:1, pp. 1-31.

Schlotthauer, Nicolas. 2000. "Currency and Financial Crises: Lessons Learned From the Asian Crises for China?” University of Wurzburg Economic Papers No. 15.

Sharma, Krishnan. 2001. "The Underlying Constraints on Corporate Bond Market Development in Southeast Asia.” World Development, 29:8, pp. 1405-19.

Sun, Laixiang and Damian Tobin. 2005. "International Listing as a Mechanism of Commitment to More Credible Corporate Governance Practices: The Case of the Bank of China (Hong Kong)." Corporate Governance: An International Review, 13:1, pp. 81-91.

Sun, Lijian. 2002. "Rethinking the Vulnerability of China's Financial System.” Finance and Trade Economics, 3, pp. 5-12. 孙立坚

“再论中国金融本系的脆弱生”, 《财贸经济》2004年第3期

Talley, Samuel, Marcelo M. Giugale, and Rossana Polastri. 1999. “Capital Inflow Reversals, Banking Stability, and Prudential Regulation in Central and Eastern Europe." World Bank Policy Research Working Paper No. 2023.

The People's Bank of China. 2006. http://www.pbc.gov.cn 
U.S. Treasury Department. 2006. "Report to Congress on International Economic and Exchange Rate Policies."

Wagner, Wolf. 2004. “The Liquidity of Bank Assets and Banking Stability.” Cambridge Endowment for Research in Finance Working Paper No. 18.

Wang, Changyun. 2005. "Ownership and Operating Performance of Chinese IPOs.” Journal of Banking and Finance, 29, pp. 1835-56.

Wu, Zhiwen. 2003. "Financial Vulnerability: Theories and Empirical Analysis on China (1991-2000).” Economic Review, 2, pp. 96-100. 伍志文

“金融脆弱生: 理论及基于中国的经验分析（1991-2000）”《经济评论》2003年第2期

Xinhua News Agency. 2005. China Money Vol. 11 No. 42.

Yu, Peter K., Gordon G. Chang, Jerome Cohen, Elizabeth C. Economy, Sharon Hom, and Adam Qi Li. 2003. “China and the WTO: Progress, Perils, and Prospects.” Columbia Journal of Asian Law, 17, pp. 1-29.

Yusuf, Shahid and Kaoru Nabeshima. 2006. "Two Decades of Reform: The Changing Organization Dynamics of Chinese Industrial Firms." World Bank Policy Research Working Paper 3806.

Zhao, Zibing. 2005. "An Analysis on the Reform Costs of Bank of China and China Construction Bank.” Securities Market Weekly, September 28, 2005.

赵自兵“中行、建行改革成本分析”,《证券市场㓮】2005年9月28日.

Zhu, Xingqiang. 2004. "Development of China Banking Industry and Restructuring Practices of BOC." Bankers' Association for Finance and Trade's $14^{\text {th }}$ Annual Conference on International Trade. 
Table 1

\section{Top 10 Leading Economies}

\section{0 and 2005}

\begin{tabular}{lcc|lcc}
\multicolumn{2}{c|}{ 1820, Share of World Total } & \multicolumn{3}{c}{ 2005, Share of World Total } \\
\hline (in percent) & GDP & Population & (in percent) & GDP & Population \\
\hline China & 28.7 & 35.7 & United States & 28.1 & 4.6 \\
India & 16.0 & 19.6 & Gapan & 10.3 & 2.0 \\
France & 5.4 & 2.9 & China & 6.3 & 1.3 \\
U.K. & 5.2 & 2.0 & U.K. & 5.0 & 20.2 \\
Prussia & 4.9 & 4.2 & France & 4.7 & 0.9 \\
Japan & 3.1 & 2.9 & Italy & 4.0 & 0.9 \\
Austria Hungary & 1.9 & 1.3 & Spain & 2.5 & 0.9 \\
Spain & 1.9 & 1.1 & Canada & 2.5 & 0.5 \\
United States & 1.8 & 0.9 & S. Korea & 1.8 & 0.7 \\
Russia & 1.7 & 1.1 & India (12 & 1.7 & 17.0 \\
\hline Top Ten Total & 70.6 & 71.7 & Top Ten Total & 70.2 & 32.7 \\
\hline
\end{tabular}

Source: World Economic Outlook, the International Monetary Fund for 2005 data and Angus Maddison, The World Economy: Volume 1: A Millennial Perspective and Volume 2: Historical Statistics, OECD, 2001 and 2003, for 1820 data.

\section{Chart 1}

\section{Pace of Economic Growth Number of Years to Double Per Capita GDP}

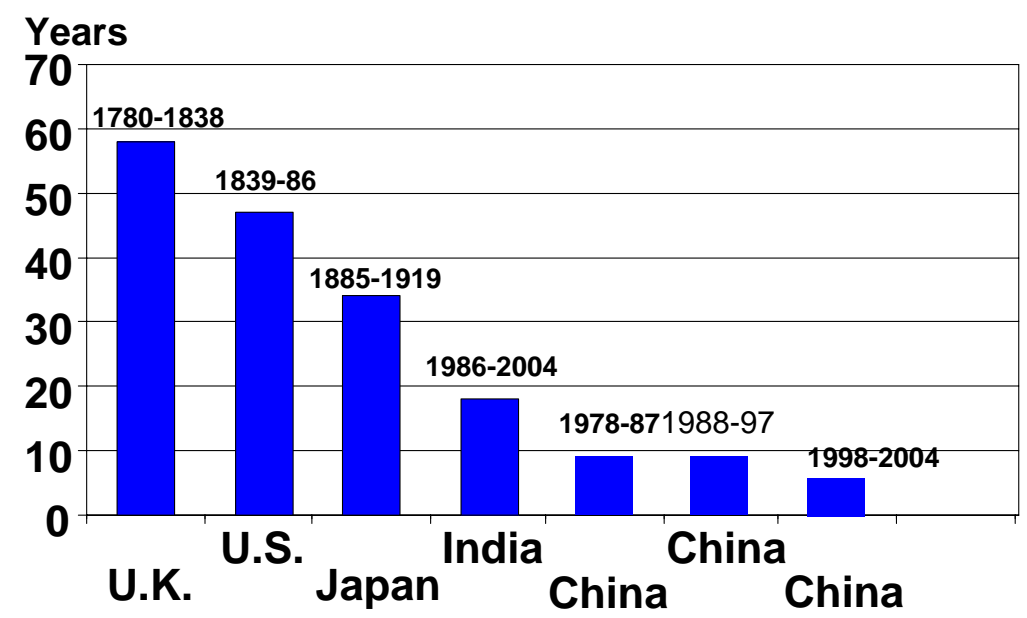


Chart 2

\section{If China and India's Rapid Growth Continues...}

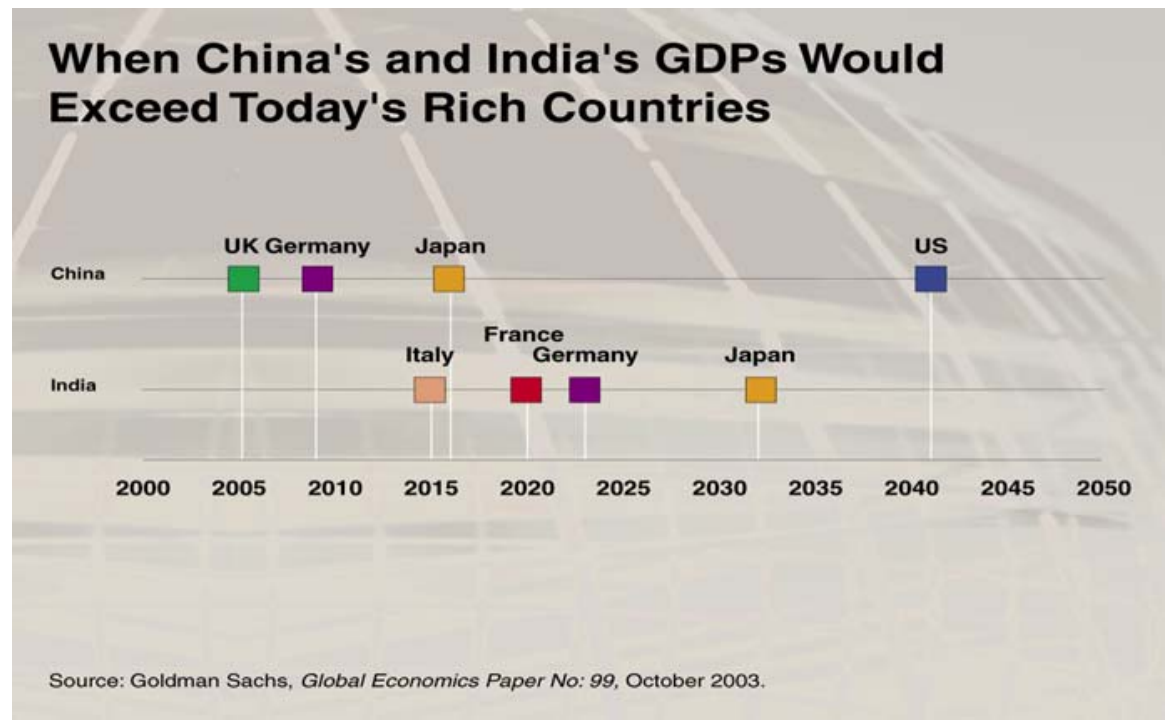

\section{Chart 3}

\section{Major Contributors to World GDP Growth 1995-2005}

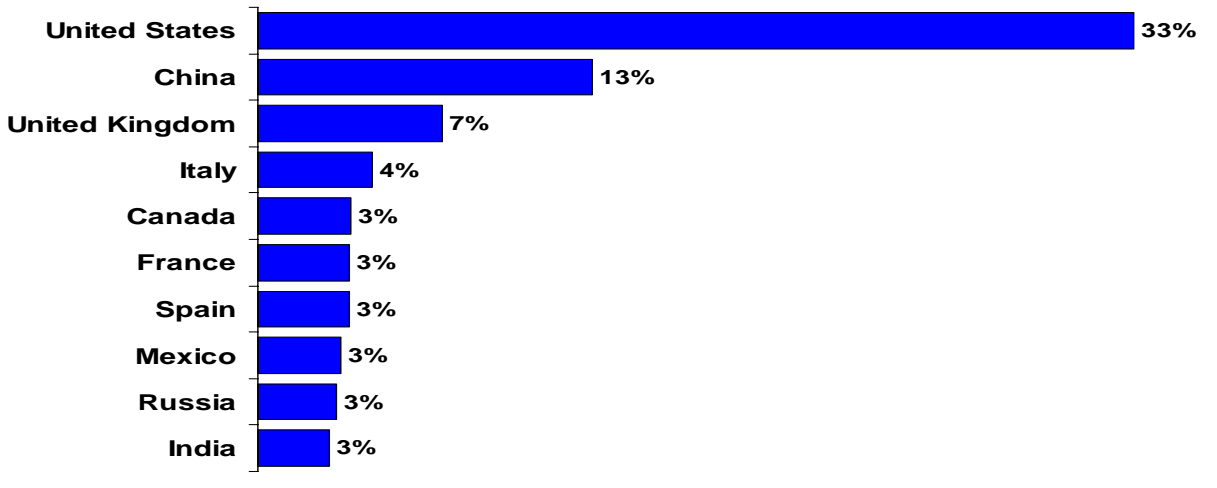

Source: World Economic Outlook, the International Monetary Fund. 
Table 2

Distribution of World's Population, GDP and Financial Assets

\section{Comparative Financial Systems}

\begin{tabular}{|c|c|c|c|c|c|c|}
\hline \multirow{2}{*}{\multicolumn{2}{|c|}{2005}} & \multicolumn{5}{|c|}{ Percent Accounted for by } \\
\hline & & \multirow{2}{*}{$\frac{\text { China }}{5.0}$} & \multirow{2}{*}{$\frac{\text { India }}{1.7}$} & \multirow{2}{*}{$\begin{array}{l}\text { U.S. } \\
28.1\end{array}$} & \multirow{2}{*}{$\frac{\text { Japan }}{10.3}$} & \multirow{2}{*}{$\frac{E U ~ 2:}{31.5}$} \\
\hline GDP & $\$ 44$ trillion & & & & & \\
\hline Population & 6.5 billion & 20.2 & 17.0 & 4.6 & 2.0 & 7.1 \\
\hline Bank Assets & $\$ 59.0$ trillion & 6.3 & 0.9 & 14.4 & 12.0 & 32.9 \\
\hline $\begin{array}{l}\text { Equity } \\
\text { Market }\end{array}$ & $\$ 35.2$ trillion & 2.0 & 1.2 & 44.8 & 13.2 & 20.7 \\
\hline Bond Market & \$58.9 trillion & 1.1 & 0.5 & 40.4 & 14.7 & 32.9 \\
\hline $\begin{array}{l}\text { Total } \\
\text { Financial } \\
\text { Assets }\end{array}$ & \$152 trillion & 3.3 & 0.8 & 31.4 & 13.3 & 30.1 \\
\hline
\end{tabular}

Source: International Financial Statistics, the International Monetary Fund, Emerging Market Fact Book, Standard and Poors, and the Quarterly Report, the Bank for International Settlements.

Table 3

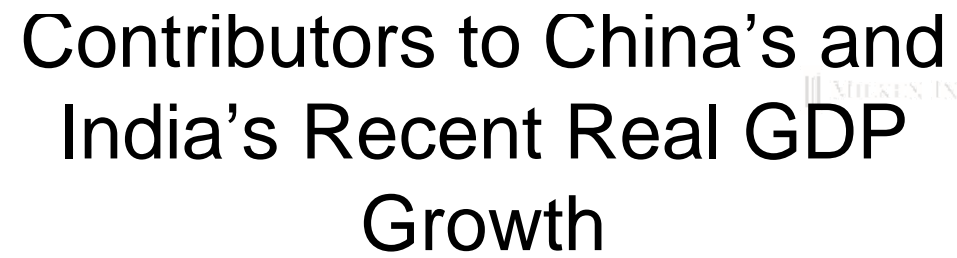

\begin{tabular}{|l|c|c|c|c|}
\hline \multirow{2}{*}{2005} & \multicolumn{2}{|c|}{ Shares of Real GDP (2004) } & \multicolumn{2}{c|}{$\begin{array}{c}\text { Component } \\
\text { Contribution to 2005 } \\
\text { Real GDP Growth }\end{array}$} \\
\cline { 2 - 5 } & China & India & China & India \\
\hline Consumption & $40 \%$ & $70 \%$ & $1 \%$ & $8 \%$ \\
\hline Government Spending & $14 \%$ & $12 \%$ & $-2 \%$ & $1 \%$ \\
\hline Investment & $43 \%$ & $26 \%$ & $7 \%$ & $3 \%$ \\
\hline Exports & $31 \%$ & $17 \%$ & $5 \%$ & $3 \%$ \\
\hline Imports & $-28 \%$ & $-25 \%$ & $-1 \%$ & $-6 \%$ \\
\hline Real GDP & $100 \%$ & $100 \%$ & & \\
\hline Real GDP Growth & & & $10 \%$ & $9 \%$ \\
\hline
\end{tabular}

Source: International Financial Statistics, the International Monetary Fund and Milken Institute estimates. 
Note: Real GDP and its components are estimated based on nominal figures deflated by price indices in the case of China because it does not publish real expenditure-side GDP.

\section{Chart 4}

\section{Investment's Contribution to China's GDP Growth, 1980 - 2005}

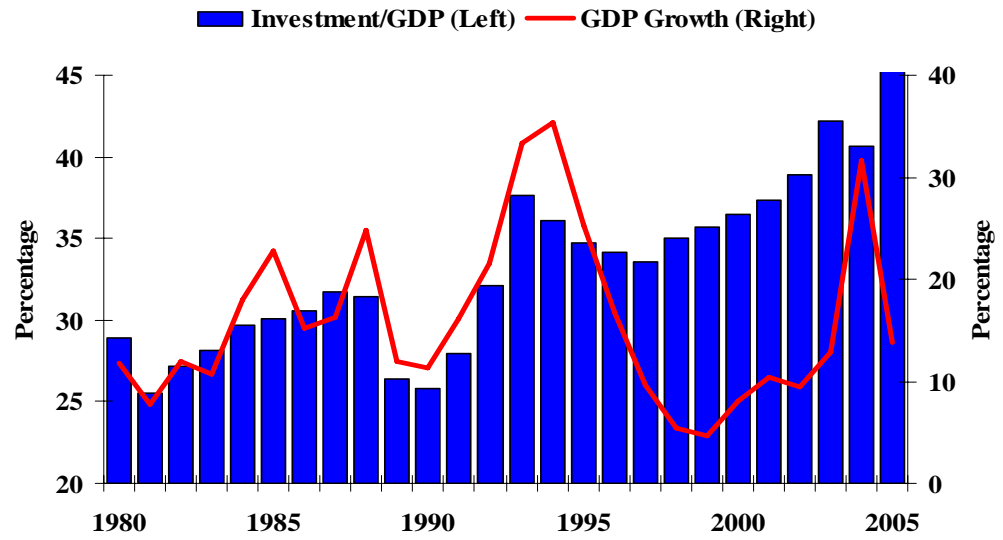

Source: International Financial Statistics, the International Monetary Fund.

\section{Table 4}

\section{Top Global Trading Nations}

\begin{tabular}{llccc}
\hline & & $\begin{array}{c}\text { Trade } \\
\text { (US\$ billions) }\end{array}$ & $\begin{array}{c}\text { GDP } \\
\text { (US\$ } \\
\text { billions) }\end{array}$ & Trade/GDP \\
\hline 1 & Euro Area & 3,047 & 9,927 & $31 \%$ \\
\hline 2 & United States & 2,640 & 12,486 & $21 \%$ \\
\hline 3 & China & 1,422 & 2,225 & $64 \%$ \\
\hline 4 & Japan & 1,110 & 4,571 & $24 \%$ \\
\hline 5 & United Kingdom & 854 & 2,201 & $39 \%$ \\
\hline 6 & Canada & 691 & 1,130 & $61 \%$ \\
\hline 7 & Hong Kong SAR & 589 & 178 & $331 \%$ \\
\hline 8 & Korea & 546 & 793 & $69 \%$ \\
\hline 9 & Mexico & 446 & 768 & $58 \%$ \\
\hline 10 & Singapore & 430 & 118 & $365 \%$ \\
\hline 18 & India & 230 & 775 & $30 \%$ \\
\hline & & & & \\
\hline
\end{tabular}

Source: Direction of Trade Statistics, the International Monetary Fund 


\section{Chart 5}

\section{Growth in Trade: China vs. India}
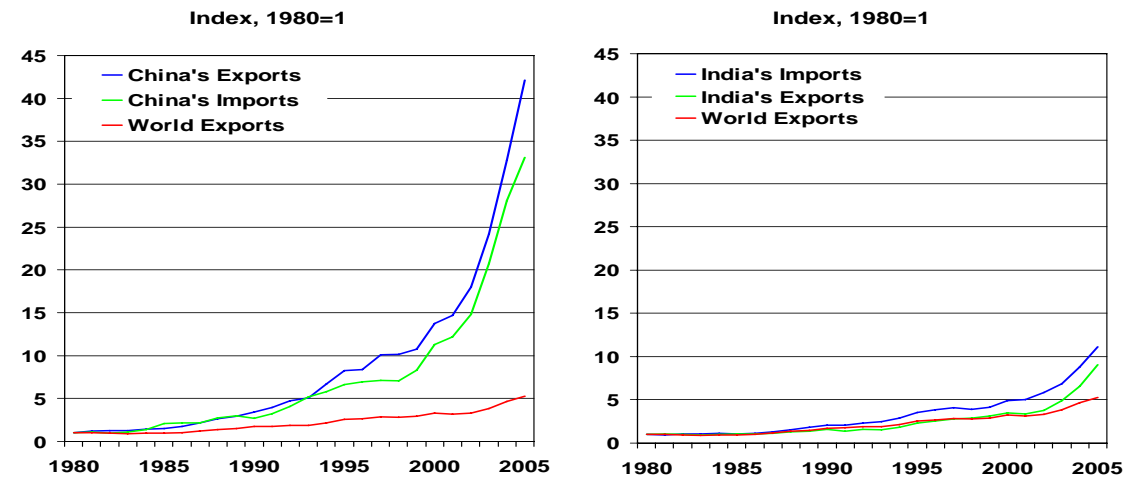

Source: International Financial Statistics, the International Monetary Fund.

\section{Chart 6}

\section{World Trade and GDP Shares: China vs. India}
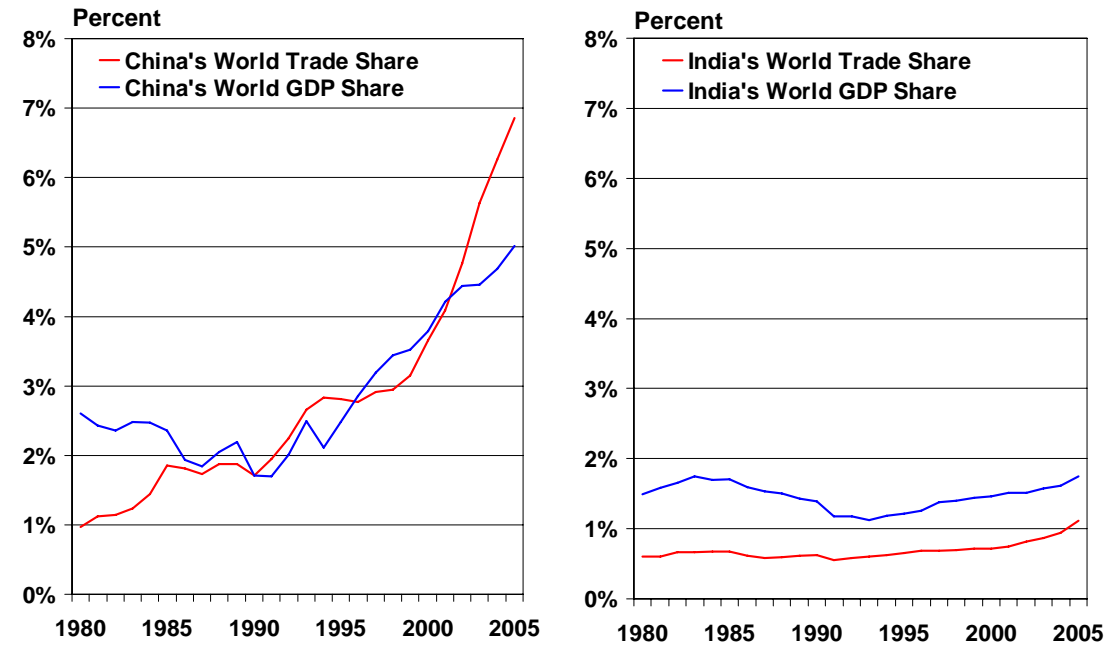

Source: International Financial Statistics, the International Monetary Fund. 


\section{Chart 7}

\section{Exchange Rates: China vs. India}

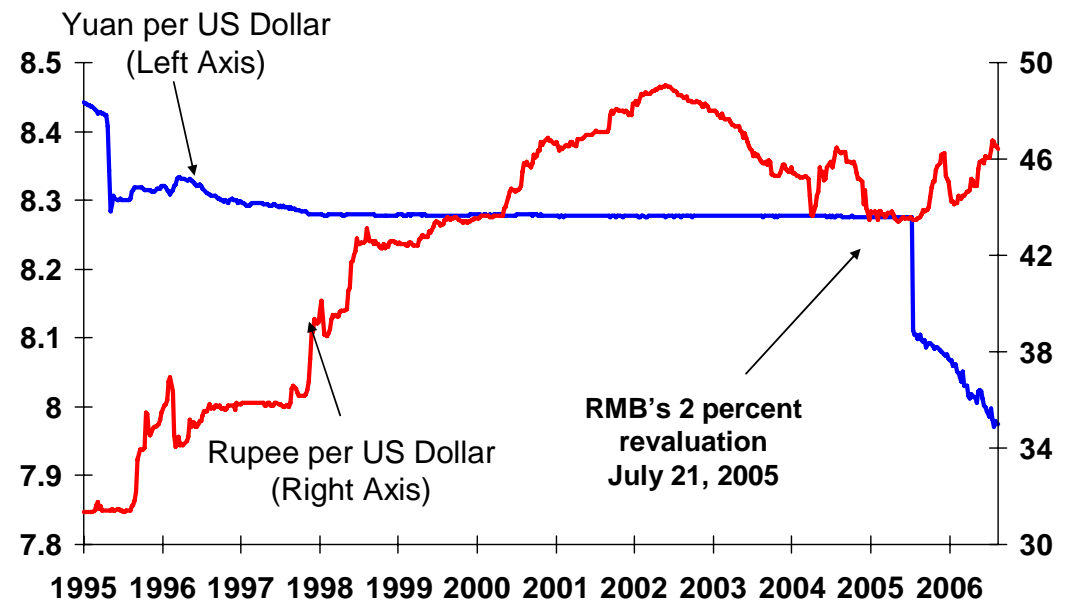

Source: International Financial Statistics, the International Monetary Fund.

\section{Chart 8}

\section{Net Private Capital Flows to} China

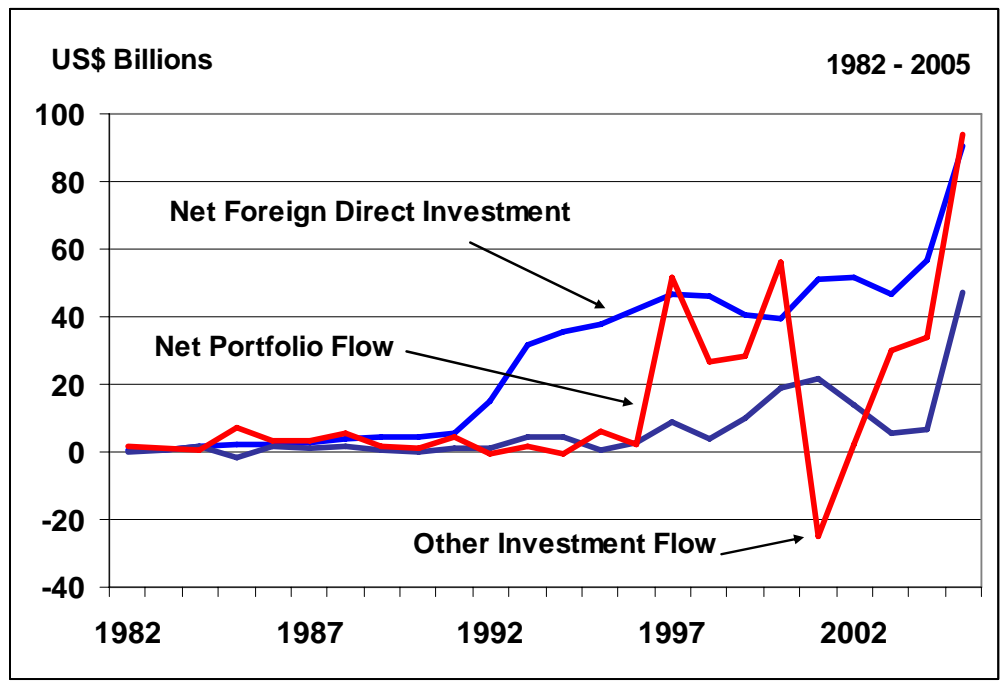

Source: International Financial Statistics, the International Monetary Fund. 


\section{Chart 9}

\section{China and India Avoid Asian Financial Crisis}

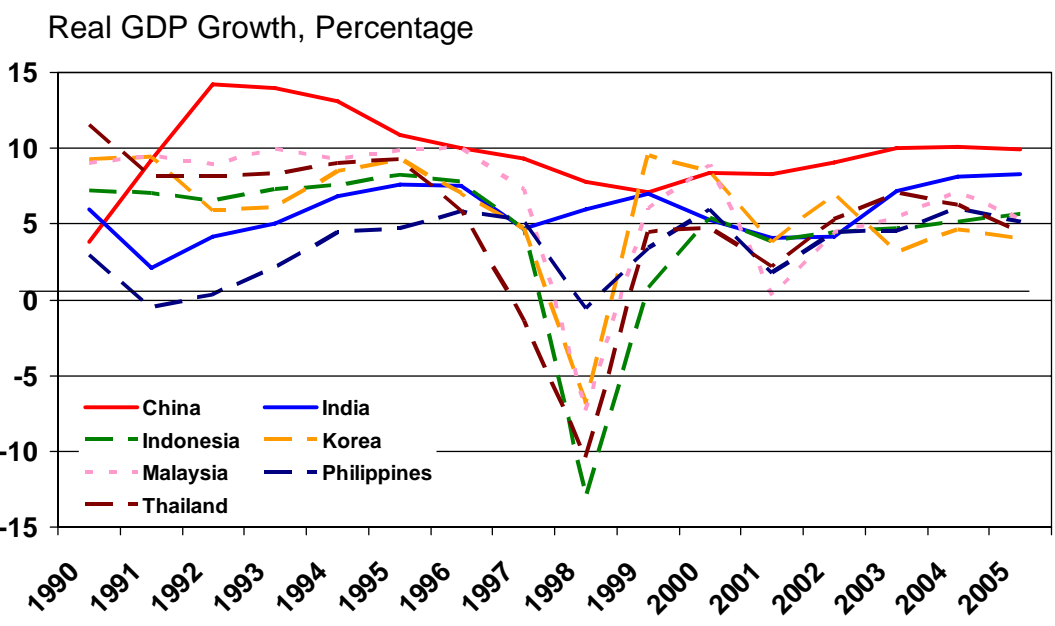

Source: World Economic Outlook and International Financial Statistics, the International Monetary Fund.

Table 5

\section{China Construction Bank June 2006}

\begin{tabular}{|l|l|l|l|}
\hline $\begin{array}{l}\text { Average Annualized } \\
\text { Cost of Deposits from } \\
\text { Customers }\end{array}$ & $1.49 \%$ & $\begin{array}{l}\text { Deposits from } \\
\text { Customers/Total Assets }\end{array}$ & $93.1 \%$ \\
\hline $\begin{array}{l}\text { Average Annualized } \\
\text { Yield on Loans and } \\
\text { Advances from } \\
\text { Customers }\end{array}$ & $5.34 \%$ & $\begin{array}{l}\text { Loans and } \\
\text { Advances/Total Assets }\end{array}$ & $54.5 \%$ \\
\hline $\begin{array}{l}\text { Average Yield on } \\
\text { Investment in Debt } \\
\text { Securities }\end{array}$ & $2.84 \%$ & $\begin{array}{l}\text { Investment in Debt } \\
\text { Securities/Total Assets }\end{array}$ & $32.5 \%$ \\
\hline Net Interest Margin & $2.70 \%$ & & \\
\hline
\end{tabular}




\section{Chart 10}

\section{Financial System Composition}

\section{5}

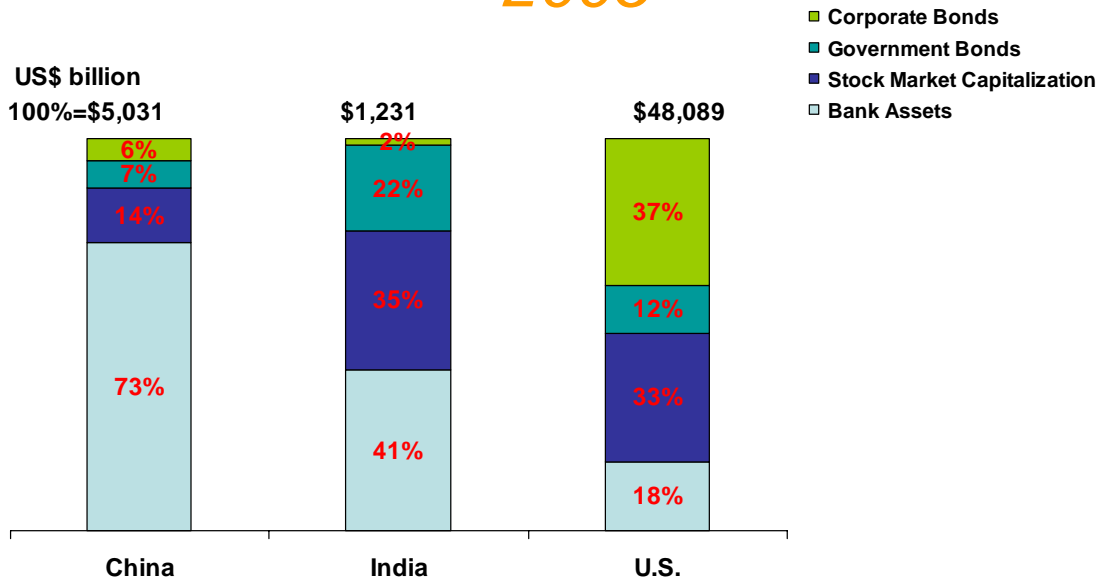

Source: International Financial Statistics, International Monetary Fund, Standard and Poors and Bank for International Settlements.

\section{Chart 11}

\section{Big Four Dominate Financial Institutions in China (2004)}
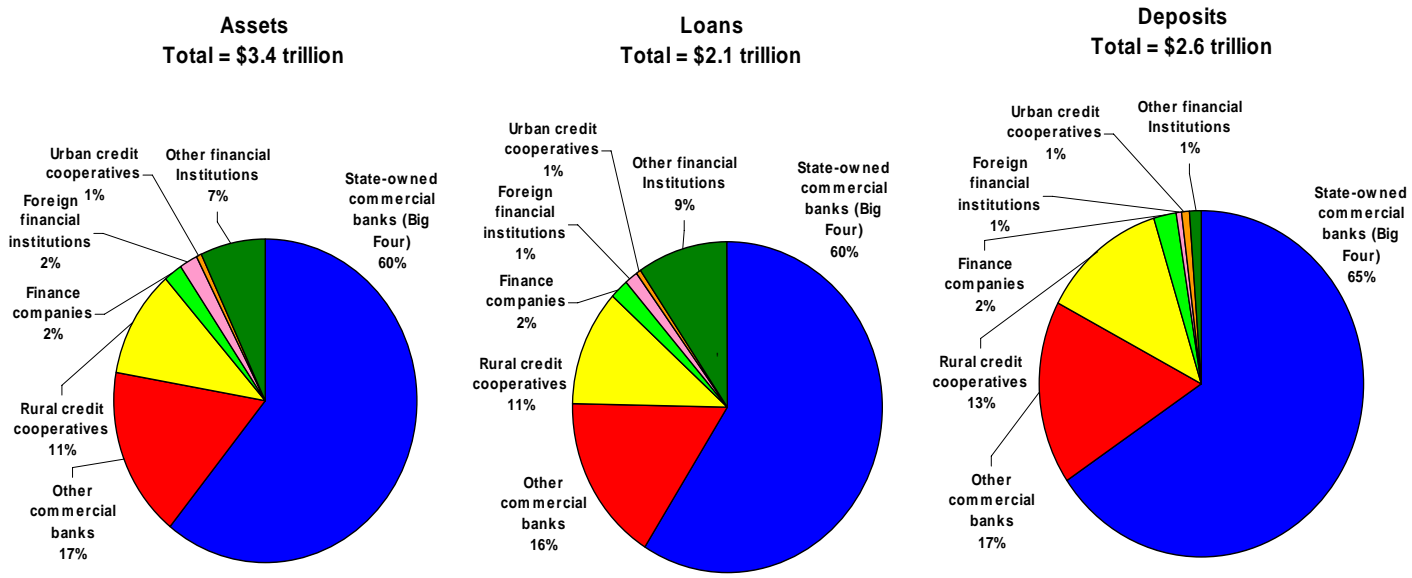
Table 6

\section{China's WTO Commitments- Banking}

\begin{tabular}{l|l|l|l}
\hline \multicolumn{1}{c|}{ Time } & Form of establishment & \multicolumn{1}{|c}{ Regions } & \multicolumn{1}{c}{ Clients } \\
\hline Entry & $\begin{array}{l}\text { Subsidiary or branches } \\
\text { subject to certain } \\
\text { (prudential) } \\
\text { requirements. }\end{array}$ & $\begin{array}{l}\text { No restrictions for foreign currency } \\
\text { business } \\
\text { RMB business: Shanghai, Shenzhen, } \\
\text { Tianjin, Dalian. }\end{array}$ & $\begin{array}{l}\text { Foreign currency } \\
\text { business: all types } \\
\text { of clients. }\end{array}$ \\
$\begin{array}{l}\text { By } 11 \\
\text { December } \\
2002\end{array}$ & $\begin{array}{l}\text { RMB business: Guangzhou, Zhuhai, } \\
\text { Qingdao, Nanjing, Wuhan. }\end{array}$ & \\
$\begin{array}{l}\text { By } 11 \\
\text { December } \\
2003\end{array}$ & $\begin{array}{l}\text { RMB business: Jinan, Fuzhou, } \\
\text { Chengdu, Chongqing. }\end{array}$ & $\begin{array}{l}\text { RMB business: } \\
\text { only to Chinese } \\
\text { enterprises. }\end{array}$ \\
$\begin{array}{l}\text { By } 11 \\
\text { December } \\
2004\end{array}$ & $\begin{array}{l}\text { RMB business: Kunming, Beijing, } \\
\text { Xiamen. }\end{array}$ & \\
$\begin{array}{l}\text { By } 11 \\
\text { December } \\
2005\end{array}$ & $\begin{array}{l}\text { RMB business: Shantou, Ningbo, } \\
\text { Xi'an. }\end{array}$ & RMB business: no geographic \\
$\begin{array}{l}\text { By } 11 \\
\text { December } \\
2006\end{array}$ & Restrictions. & $\begin{array}{l}\text { RMB business: to } \\
\text { all Chinese clients. }\end{array}$ \\
\hline
\end{tabular}

Table 7

\section{Nonperforming Loans to Total Loans of the Big Four}

(percentages, end of year)

\begin{tabular}{lccccc}
\hline & 2001 & 2002 & 2003 & 2004 & 2005 \\
\hline Agricultural Bank of China & 41.4 & 36.7 & 30.7 & 26.8 & 26.3 \\
$\begin{array}{l}\text { Industrial and Commercial Bank of } \\
\text { China }\end{array}$ & 29.8 & 25.5 & 21.3 & 19.1 & 4.7 \\
Bank of China & 27.5 & 22.4 & 15.9 & 5.1 & 4.6 \\
\hline $\begin{array}{l}\text { China Construction Bank } \\
\text { Aggregate of the Big Four }\end{array}$ & 19.4 & 15.4 & 9.1 & 3.7 & 3.8 \\
\hline
\end{tabular}

Source: People's Bank of China and China Banking Regulatory Commission. 
Table 8

\section{NPLs Disposed of by Asset Management Corporations, 2005}

\begin{tabular}{lcccc}
\hline & $\begin{array}{c}\text { NPLs disposed } \\
\text { of, 1999 to 2005 } \\
\text { (\$ billion) }\end{array}$ & $\begin{array}{c}\text { NPLs } \\
\text { disposed of }\end{array}$ & $\begin{array}{c}\text { Cash and non cash } \\
\text { received /NPLs } \\
\text { disposed of }\end{array}$ & $\begin{array}{c}\text { Cash received } \\
\text { INPLs } \\
\text { disposed of }\end{array}$ \\
\hline $\begin{array}{l}\text { Huarong } \\
(B O C)\end{array}$ & 30.1 & $69.2 \%$ & $26.9 \%$ & $22.3 \%$ \\
$\begin{array}{l}\text { Great Wall } \\
\text { (ABC) }\end{array}$ & 32.6 & $77.9 \%$ & $12.9 \%$ & $10.4 \%$ \\
$\begin{array}{l}\text { Oriental } \\
\text { (ICBC) }\end{array}$ & 16.3 & $52.1 \%$ & $28.7 \%$ & $24.3 \%$ \\
\hline $\begin{array}{l}\text { Cinda } \\
(\text { CCB })\end{array}$ & 24.9 & $63.8 \%$ & $34.3 \%$ & $31.2 \%$ \\
\hline Total & 103.9 & $\mathbf{6 6 . 7 \%}$ & $\mathbf{2 4 . 6 \%}$ & $\mathbf{2 1 . 0 \%}$ \\
\hline
\end{tabular}

Source: China Banking Regulatory Commission.

\section{Table 9}

\section{China's Reported Nonperforming Loans (2005)}

\begin{tabular}{lccc}
\hline & \multicolumn{3}{c}{ Nonperforming Loans } \\
& $\begin{array}{c}\text { Amount } \\
\text { (\$ billion) }\end{array}$ & $\begin{array}{c}\text { \% of } \\
\text { Total Loans }\end{array}$ & $\begin{array}{c}\text { \% of } \\
\text { GDP }\end{array}$ \\
\hline $\begin{array}{l}\text { State owned commercial banks } \\
\text { (Big Four) }\end{array}$ & 132.7 & 10.5 & 5.9 \\
Joint stock commercial banks & 18.2 & 4.2 & 0.8 \\
City commercial banks & 10.4 & 7.7 & 0.5 \\
\hline Rural commercial banks & 0.7 & 6.0 & $<1$ \\
Foreign banks & 0.5 & 1.1 & $<1$ \\
\hline Total & $\mathbf{1 6 2 . 5}$ & $\mathbf{8 . 6}$ & $\mathbf{7 . 2}$ \\
\hline Memo: & & & \\
\hline \multicolumn{1}{c}{ Asset Management Corporations } & 51.8 & & 2.3 \\
\hline
\end{tabular}


Table 10

\section{Equity to Total Assets of the Big Four}

\begin{tabular}{lcccccc}
\hline (percentages) & $\mathbf{2 0 0 0}$ & $\mathbf{2 0 0 1}$ & $\mathbf{2 0 0 2}$ & $\mathbf{2 0 0 3}$ & $\mathbf{2 0 0 4}$ & $\mathbf{2 0 0 5}$ \\
\hline $\begin{array}{l}\text { Agricultural Bank of China } \\
\begin{array}{l}\text { Industrial and Commercial Bank of } \\
\text { China }\end{array}\end{array}$ & 6.2 & 5.3 & 4.6 & 4.0 & 1.9 & 1.7 \\
$\begin{array}{l}\text { Bank of China } \\
\text { China Construction Bank }\end{array}$ & 6.1 & 6.6 & 6.7 & 5.8 & 5.5 & 4.9 \\
\hline Aggregate of the Big Four & 4.5 & 3.9 & 4.7 & 5.3 & 5.0 & 6.3 \\
\hline
\end{tabular}

Source: BankScope.

\section{Table 11}

\section{Big Four Performance Compared to Foreign Banks and Citibank (2005)}
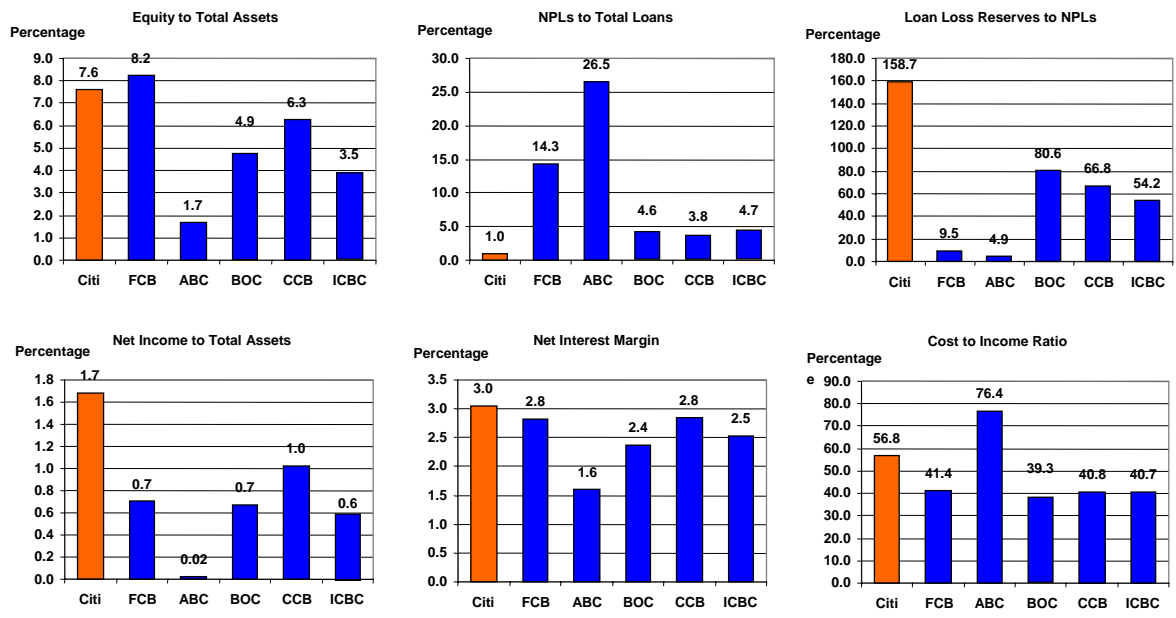

Source: BankSope. 


\section{Chart 12}

\section{Nonperforming Loans of Big Four}

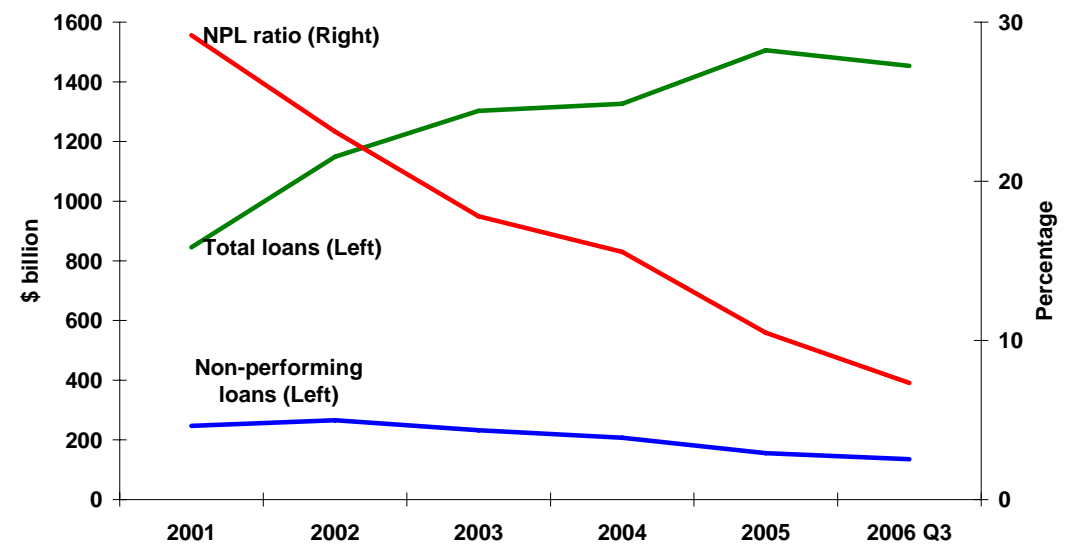

Source: People's Bank of China, China Banking Regulatory Commission and various press releases.

\section{Chart 13}

\section{Bank Lending and Deposit Rates (1 year)}

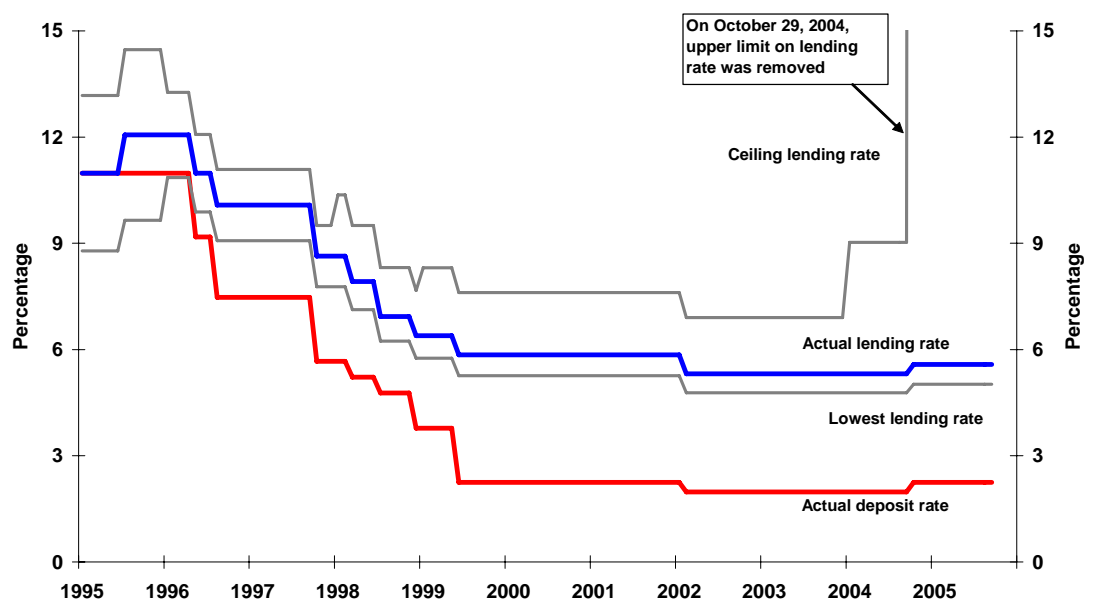




\section{Chart 14}

\section{Private Enterprises: Contribution to GDP vs. Share of Corporate Bank Loans}
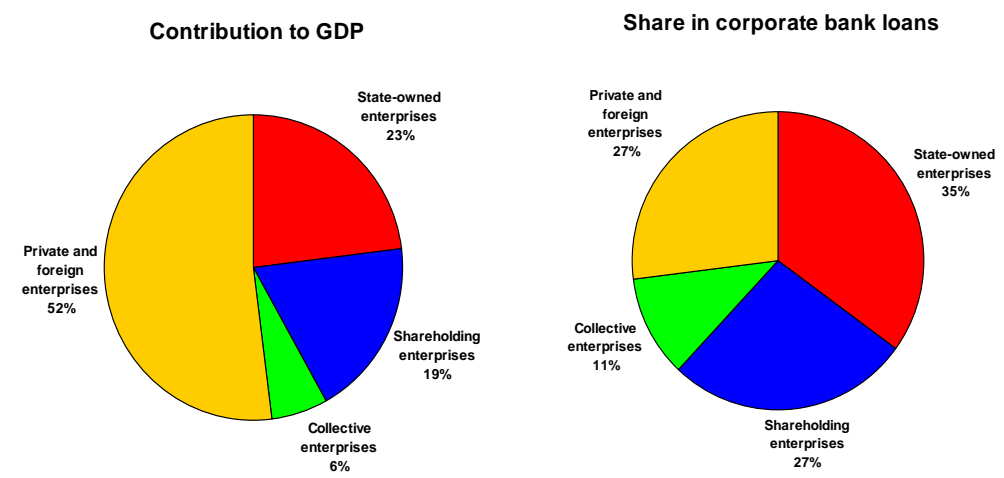

Source: National Bureau of Statistics and the People's Bank of China.

\section{Chart 15}

\section{Most Bank Loans Go to Large Firms}

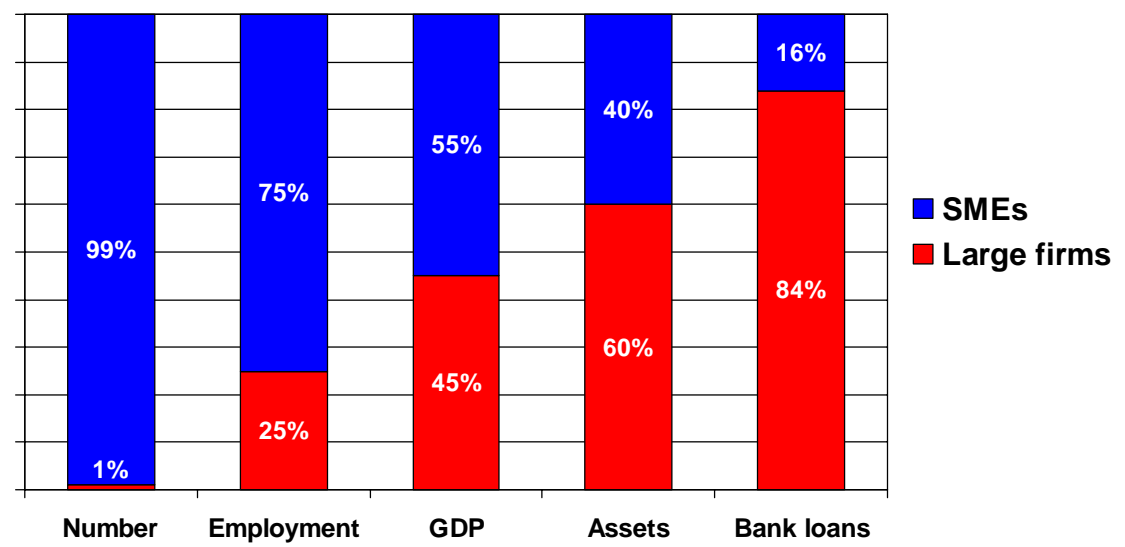

Source: National Bureau of Statistics and the People's Bank of China 


\section{Figure 1.}

\section{The Financial Regulatory Structure in China}

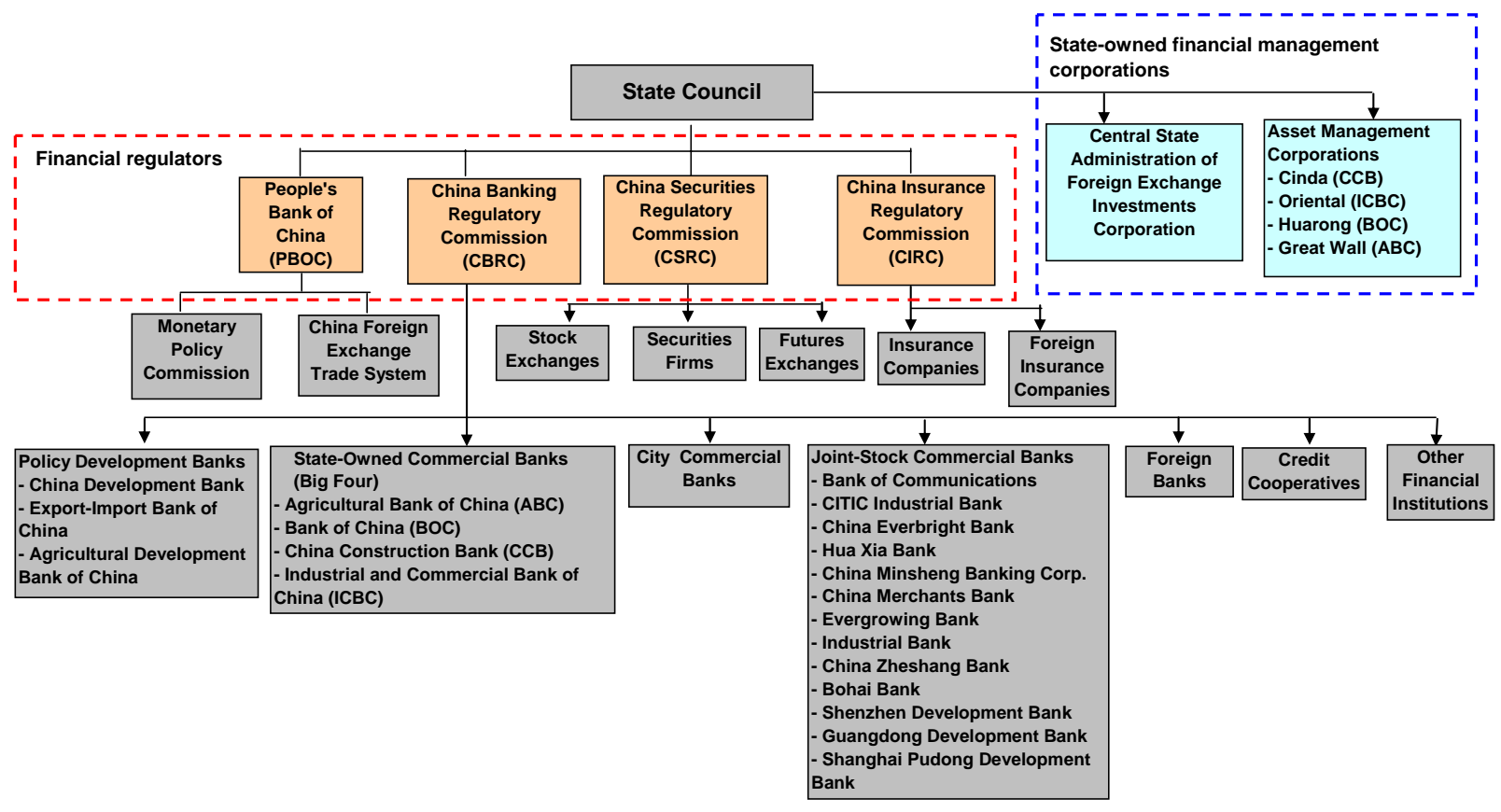




\section{Appendix 1.}

\section{Countries’ Financial System Differ Widely}

\begin{tabular}{|c|c|}
\hline $\begin{array}{l}\text { Size of Financial Systems } \\
\text { Financial Assets/GDP }\end{array}$ & $\begin{array}{l}\text { Size of Equity Markets } \\
\text { Equity/GDP }\end{array}$ \\
\hline U.K. Japan Taiwan U.S. Germany South China Brazil India & 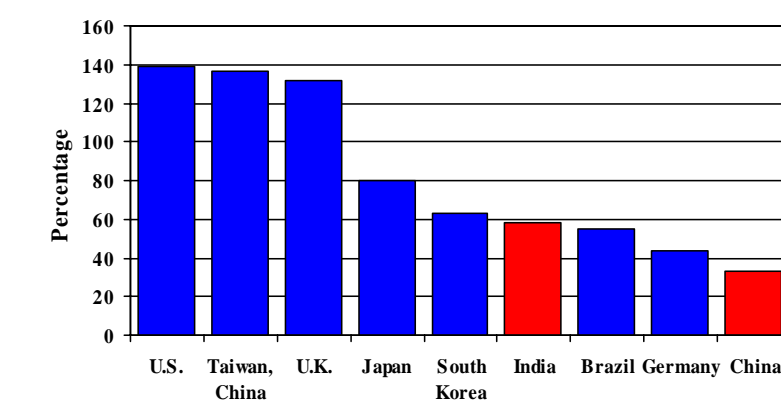 \\
\hline $\begin{array}{l}\text { Size of Bond Markets } \\
\text { Bonds/GDP }\end{array}$ & $\begin{array}{l}\text { Share of Government Bonds in Bond } \\
\text { Markets } \\
\text { Government Bonds / Total Bond Market }\end{array}$ \\
\hline 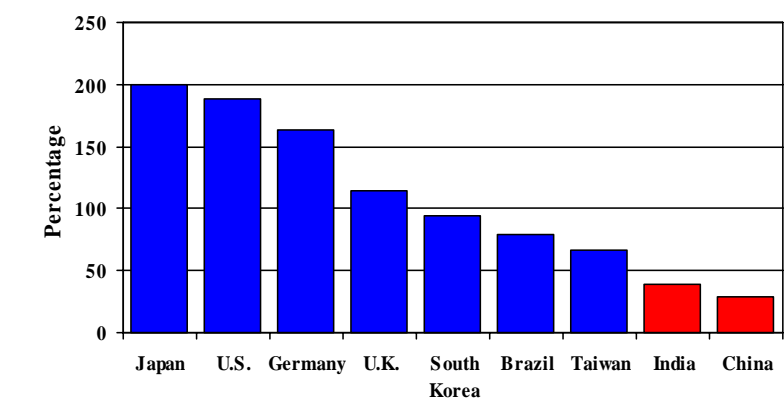 & 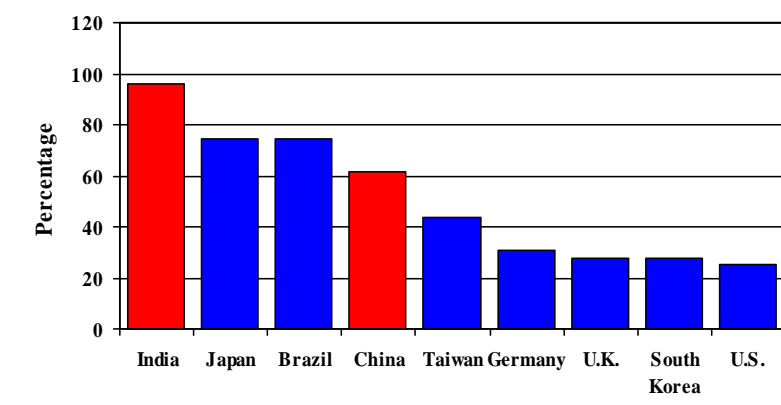 \\
\hline
\end{tabular}

Source: International Financial Statistics, International Monetary Fund; Emerging Market Fact Book, Standard and Poor's; and Quarterly Review, the Bank for International Settlements. 
Appendix 2. China's and India's International Investment Positions, 2005

\begin{tabular}{ccc}
\hline US\$ billions & China & India \\
\hline Net Foreign Assets & 288 & -41 \\
Gross Foreign Assets & 1,219 & 169 \\
Equity & 65 & 10 \\
of which FDI & 65 & 10 \\
Debt & 328 & 18 \\
Reserves & 826 & 142 \\
Gross Foreign Liabilities & 931 & 210 \\
Equity & 674 & 87 \\
of which FDI & 610 & 45 \\
Debt & 257 & 123 \\
\hline
\end{tabular}

Source: International Financial Statistics, the International Monetary Fund. 